\title{
Assessing Microglial Dynamics by Live Imaging
}

\author{
Megumi Andoh and Ryuta Koyama* \\ Laboratory of Chemical Pharmacology, Graduate School of Pharmaceutical Sciences, The University of Tokyo, Tokyo, Japan
}

OPEN ACCESS

Edited by:

Amanda Sierra,

Achucarro Basque Center for

Neuroscience, Spain

Reviewed by:

Ukpong Bassey Eyo,

University of Virginia, United States

Marie-Eve Tremblay,

University of Victoria, Canada

*Correspondence:

Ryuta Koyama

rkoyama@mol.f.u-tokyo.ac.jp

Specialty section:

This article was submitted to

Multiple Sclerosis and

Neuroimmunology,

a section of the journal

Frontiers in Immunology

Received: 15 October 2020

Accepted: 16 February 2021

Published: 08 March 2021

Citation:

Andoh M and Koyama R (2021) Assessing Microglial Dynamics by Live Imaging. Front. Immunol. 12:617564.

doi: 10.3389/fimmu.2021.617564
Microglia are highly dynamic in the brain in terms of their ability to migrate, proliferate, and phagocytose over the course of an individual's life. Real-time imaging is a useful tool to examine how microglial behavior is regulated and how it affects the surrounding environment. However, microglia are sensitive to environmental stimuli, so they possibly change their state during live imaging in vivo, mainly due to surgical damage, and in vitro due to various effects associated with culture conditions. Therefore, it is difficult to perform live imaging without compromising the properties of the microglia under physiological conditions. To overcome this barrier, various experimental conditions have been developed; recently, it has become possible to perform live imaging of so-called surveillant microglia in vivo, ex vivo, and in vitro, although there are various limitations. Now, we can choose in vivo, ex vivo, or in vitro live imaging systems according to the research objective. In this review, we discuss the advantages and disadvantages of each experimental system and outline the physiological significance and molecular mechanisms of microglial behavior that have been elucidated by live imaging.

Keywords: microglia, synapse, slice culture, acute slice, multiphoton/two-photon imaging, quadripartite synapse, microglial process, microglial motility

\section{INTRODUCTION}

Under physiological conditions, microglia have multiple finely branched protrusions, i.e., ramified processes, that constantly extend, and retract to monitor the extracellular environment (1-3). This dynamic process extension and retraction is characteristic of microglia, as neurons and astrocytes do not show significant morphological changes of their primary processes. These properties of microglia cannot be overlooked because they modulate microglial functions: production and directed release of inflammatory mediators, phagocytosis of pathogens and aggregate proteins, and cell-cell contacts (4). However, without a live imaging system, it is difficult to verify these phenomena; for example, if microglial density increases in a region as a result of observing fixed specimens, it is unclear whether this is due to microglial proliferation or migration. Additionally, it is difficult to discriminate whether increased cytokine expression or increased phagocytosis is the cause or effect of changes in the surrounding environment. Thus, understanding the molecular mechanisms and physiological significance of microglial motility requires direct live imaging of microglia while performing genetic and pharmacological manipulations.

Real-time imaging of microglia is essential; however, it is extremely difficult to observe microglia in their endogenous state in the brain. This is because microglia are sensitive to changes in the extracellular environment and can easily change their state during preparatory steps in experimental procedures, such as craniotomy (removal of the skull and replacement with a glass coverslip to allow transcranial viewing) for in vivo imaging, brain slice preparation for ex vivo imaging, and brain isolation for preparing cultures for in vitro imaging. More specifically, this 
may occur by surgical damage when performing live imaging in vivo and by various influences associated with culture conditions when performing live imaging in vitro, such as the presence or absence of other types of cells, the contents, serum, $\mathrm{pH}$, and osmolality of the medium (5-8). Thus, if the microglia have already responded to the process of preparation in experiments, there is a possibility that further response of microglia by stimuli, including physical or pharmacological stimulation, may be underestimated, masked, or altered.

The spatiotemporal resolution of real-time imaging of microglia has improved considerably in recent years due to a variety of conditional investigations of observational techniques to overcome problems mentioned above. In this review, we highlight studies that performed live imaging of microglia in vivo, ex vivo (acutely prepared brain slices and organotypic brain slice cultures), and in vitro (dispersed culture of primary microglia). We further review the results of these studies, which are important for improving our understanding of microglial function and identity. In particular, it has been reported that the basic morphology and motility of microglial processes seen in vivo can be to some extent reproduced in acute slice and slice cultures (Figure 1). Therefore, in the following sections, observed phenomena (i.e., migration and phagocytosis), animal types (mouse, rat, and zebrafish), sample preparation methods (i.e., craniotomy, preparation of brain slices, and isolation of microglia from the brain), imaging conditions, and quantifiable parameters are compared to help microglial researchers interpret findings from live imaging studies and select appropriate methods for observing microglial dynamics.

\section{IN VIVO LIVE IMAGING}

\section{Essential Methods for in vivo Live Imaging Preparation of Imaging Window}

Mice and zebrafish have been often used for in vivo live imaging of microglia (Table 1). As the whole body including the brain of zebrafish is transparent, high-resolution imaging can be expected in any region if the sample is properly embedded and fixed in a gel. On the other hand, in case of mice, it is necessary to surgically create an imaging window because the skin and skull are not transparent enough for live imaging of the brain.

Since 2005, there has been increasing research on in vivo live imaging of microglia, and now thinned skull and open skull are recognized as the two major methods for preparing imaging window. The pros and cons of each method are well-summarized in the review article by Dorand et al. (48). Removing skull could stimulate microglia and change their state, and it requires several weeks for microglia to return to the physiological state $(5,16)$. The open skull method, on the other hand, has the advantage of a wider imaging depth and higher resolution than the thinned skull method $(46,49)$. Abnormal changes in microglial state induced by removing skull are critical not only because it affects the morphology and motility of microglia themselves, but also because cytokines released by microglia could affect the properties of surrounding cells. Although Isshiki and Okabe reported that they could not observe synaptic structures clearly using through the thinned skull (31), several studies have reported successful observation of synaptic structures such as dendritic spines in vivo through a thin-skull window $(24,44,46,47)$.

It is important to consider whether to use an open skull method or a thinned skull method, depending on the brain region or phenomenon being targeted. It should also be noted that both methods require technical proficiency of the experimenter to increase the success rate, and that there are difficulties in in vivo live imaging to achieve a high level of imaging between specimens.

\section{Anesthesia}

Proper anesthesia of animals is essential for in vivo live imaging. Live imaging with awake animals using head fixation is possible, and although many papers have been published on awake imaging, there is no doubt that anesthesia is useful for reducing motion artifacts, which may affect live imaging of microstructures such as synapses and microglial filopodia, and achieving more stable imaging. However, there is still the problem that the activity of each brain cell (including neuronal firing and microglial motility) is affected by anesthesia. For example, anesthesia suppresses neuronal firing activity (50) and alters the turnover rate of dendritic spines $(40,51)$. In recent years, it has been reported that anesthesia affects not only neuronal activity but also microglial motility, and the way in which this is affected depends on the type of anesthesia. For example, isoflurane, one of the most commonly used anesthetics, reduces the motility of microglial processes by inhibiting the potassium channel THIK-1 in acutely sectioned brain slices, whereas urethane has no such effect (52). On the other hand, live-imaging studies have also suggested that isoflurane enhanced microglial surveillance by increasing the length and velocity of surveilling processes as well as the frequency of extension and retraction of processes during both physiological and pathological conditions $(33,41,42)$. It has also recently been shown that ketamine/xylazine, which is as frequently used as isoflurane, reduces the morphological complexity and process motility of microglia under physiological conditions (29). Morphological changes in microglia are likely to result in functional changes, and it is almost certain that anesthesia will influence experimental results and their interpretation. It is hoped that further research will reveal which anesthetics are able to preserve microglial properties in the awake state.

\section{Phenomena Verified by in vivo Live Imaging Colonization of Microglia}

During the embryonic period, microglia migrate from the yolk sac to the brain parenchyma. In 2016, Xu et al. observed the migration of microglia in zebrafish larvae using live imaging (53). The advantage of using zebrafish larvae is their small size and high transparency. This makes it possible to obtain highresolution images of cell motility in vivo. Another attraction is the wide range of transgenic lines available, allowing live imaging of cells without viral infection or injection of fluorescent reagents. In addition, molecules involved in the detection and phagocytosis of dead cells by microglia are conserved in vertebrates, and if the observed phenomenon is carefully interpreted, it may 


\section{A Large process}

Extension $\square$ Retraction $\square$ Average or Not identified

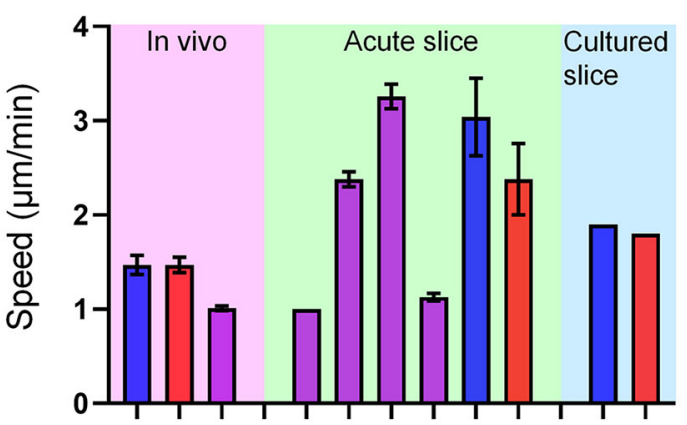

B Filopodia

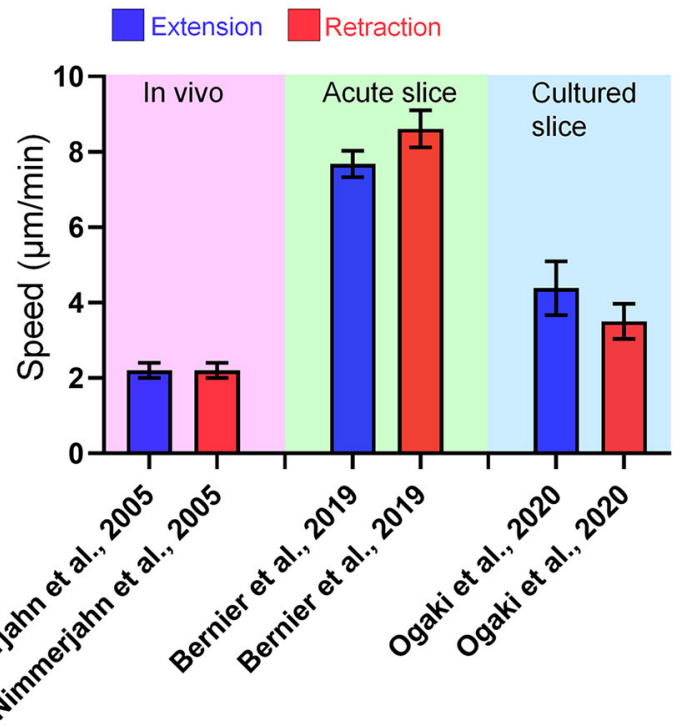

FIGURE 1 | Microglial process motility in each live-imaging condition. (A) Speed of large process motility of microglia reported in papers referred in this review. In some cases, the speed of process motility was not specified as "extraction" or "retraction." (B) Speed of filopodia motility of microglia reported in papers referred in this review. In Bernier et al. (9), the authors defined tiny protrusions near the tip of large process as filopodia, and provided the quantitative data of filopodia and large process. In Nimmerjahn et al. (1) and Ogaki et al. (10), short branches that emanated from the primary process of microglia were regarded as filopodia.

be possible to extrapolate and validate findings acquired from studies using zebrafish to mammals. $\mathrm{Xu}$ et al. found that microglial progenitor cells infiltrate the optic tectum through a circulation-independent pathway. In addition, based on the fact that neuronal death occurs in the optic tectum during microglial migration, the authors investigated the possibility that apoptotic cells are involved in microglial migration. Suppression of neuronal cell death by overexpression of the anti-apoptotic protein bcl-2 significantly suppressed microglial infiltration into the optic tectum. Furthermore, ATP and lysophosphatidylcholine (LPC) released from apoptotic cells were identified as molecules that promote infiltration.

Casano et al. published a paper around the same time as $\mathrm{Xu}$ et al. in which they also examined the relationship between developmental microglial colonization and apoptotic cells (15). Suppression of neuronal cell death by administration of the caspase inhibitor Z-VAD-fmk or promotion of neuronal cell death by UV irradiation inhibited or promoted microglial infiltration to the brain parenchyma, respectively. Next, they showed that inhibition of nucleic acid release by pannexin-1a knockdown or inhibition of purinergic receptors by suramin suppressed microglial infiltration. A study using live imaging of acute slices of mouse embryonic cerebral cortex (54) reported that the migration rate of microglia is higher in the earlier embryonic period, which may be due to differential concentrations of apoptotic cell-derived molecules.

Contrary to the findings by $\mathrm{Xu}$ et al. (53), there are reports suggesting that the infiltration of microglia into the parenchyma is circulation-dependent in the fetal mouse brain
(55). Furthermore, in live imaging of acute hippocampal slices prepared from 1-week-old mice, Eyo et al. showed that knockout of the apoptotic protein BAX did not affect microglial morphology or motility, and concluded that apoptotic cells do not regulate microglial dynamics (56). Thus, it is quite possible that the same phenomenon has different underlying mechanisms in different species.

Askew et al. examined the mechanism of microglial population maintenance by live imaging over 22 days (12). Interestingly, immediately after division, newborn microglia exhibited a 2 -fold higher mortality rate than resident microglia. Furthermore, the authors found that microglial division is spatiotemporally coupled with microglial mortality. The molecular mechanism of this coupling has not been clarified, but CSF1R, which is essential for microglial survival, and IL-1R, which promotes microglial repopulation, have been considered as candidates.

Microglial proliferation is known to be enhanced in the brain following neurodegeneration and injury. Füger et al. developed an impressive method to examine the rate of microglial proliferation and turnover (22). The authors successfully fluorescently labeled single microglia within the field of view by using CD11b-CreERT2;R26-tdTomato mice with modified tamoxifen administration. They followed the same microglial fate with biweekly imaging for 6 months and with monthly imaging afterwards (starting at 4 months of age). It was reported that both the proliferation and disappearance rates of microglia were $13 \%$. The median survival time was 15 months, which means that approximately half of all microglia in mice are present for 
TABLE 1 | Experimental conditions of live imaging of microglia in vivo.

\begin{tabular}{|c|c|c|c|c|c|c|c|c|c|c|}
\hline Animal & Age & Skull & Anesthesia & $\begin{array}{l}\text { Region (depth } \\
\text { from the } \\
\text { surface) }\end{array}$ & Cellular visualization & Microscopy & Objective lens & $\begin{array}{l}\text { Resolution }(x, y) \\
z \text { stack }\end{array}$ & $\begin{array}{l}\text { Interval time } \\
\text { Total time }\end{array}$ & References \\
\hline $\begin{array}{l}\text { CX3CR1-GFP }+/- \\
\text { mice }\end{array}$ & $2 \mathrm{mo}$ & Thinned & Isoflurane & Cortex & GFP (microglia) & Two-photon & $25 \times(N A=1.05)$ & $\begin{array}{l}- \\
1 \mu \mathrm{m} \text { step }\end{array}$ & $\begin{array}{l}1.5 \mathrm{~min} \\
13.5 \mathrm{~min}\end{array}$ & $\begin{array}{l}\text { Abiega et al. } \\
\text { (11) }\end{array}$ \\
\hline $\begin{array}{l}\text { CX3CR1-GFP }+/- \\
\text { mice }\end{array}$ & 8-12 mo & Open & Isoflurane & Cortex & GFP (microglia) & Two-photon & $20 \times(N A=1.0)$ & $\begin{array}{l}317 \times 317 \mu \mathrm{m} \\
50-80 \mu \mathrm{m} \text { with } 1 \mu \mathrm{m} \\
\text { step }\end{array}$ & -22 days & $\begin{array}{l}\text { Askew et al. } \\
\text { (12) }\end{array}$ \\
\hline $\begin{array}{l}\text { CX3CR1-GFP+/- } \\
\text { mice }\end{array}$ & 8-10 wo & Thinned & - & $\begin{array}{l}\text { Cortex } \\
(100-150 \mu \mathrm{m})\end{array}$ & $\begin{array}{l}\text { GFP (microglia) } \\
\text { mCherry (axonal bouton) }\end{array}$ & Two-photon & $25 \times(N A=1.10)$ & $\begin{array}{l}1,024 \times 1,024 \text { pixel } \\
(0.1269 \mu \mathrm{m} / \text { pixel }) \\
1 \mu \mathrm{m} \mathrm{step}\end{array}$ & $\begin{array}{l}1 \mathrm{~min} \\
3 \mathrm{~h}\end{array}$ & $\begin{array}{l}\text { Badimon } \\
\text { et al. (13) }\end{array}$ \\
\hline C57BL/6 mice & $2-6 \mathrm{mo}$ & Thinned & Isoflurane & $\begin{array}{l}\text { Somatosensory } \\
\text { cortex }(\sim 330 \mu \mathrm{m})\end{array}$ & Twitch-2B (microglia) & Confocal & $\begin{array}{l}20 \times(N A=1.0) \\
40 x(N A=0.8)\end{array}$ & $0.15-0.31 \mu \mathrm{m} /$ pixel & $\begin{array}{l}1 \text { frame } / \mathrm{s}, 10 \mathrm{~min} \\
\text { or } 0.13 \mathrm{frame} / \mathrm{s} \text {, } \\
30-120 \mathrm{~s}\end{array}$ & $\begin{array}{l}\text { Brawek et al. } \\
\text { (14) }\end{array}$ \\
\hline $\begin{array}{l}\text { pU.1::Gal4- } \\
\text { UAS::TagRFP, } \\
\text { mpeg1::Gal4- } \\
\text { UAS::Kaede, } \\
\text { nbt::DlexPR::NTR- } \\
\text { mCherry, and } \\
\text { slc7a7::Kaede } \\
\text { (zebrafish) }\end{array}$ & $2-3 \mathrm{dpf}$ & - & $0.01 \%$ tricaine & & $\begin{array}{l}\text { RFP, Kaede (microglia) } \\
\text { mCherry (neuron) }\end{array}$ & Confocal & $\begin{array}{l}20 x(N A=0.4) \\
10 x(N A=0.25)\end{array}$ & $\begin{array}{l}- \\
\text { 30-40 planes with } \\
1.5-2 \mu \mathrm{m} \mathrm{step}\end{array}$ & - & $\begin{array}{l}\text { Casano et al. } \\
\text { (15) }\end{array}$ \\
\hline C57BL/6 mice & P4-19 & Open & Isoflurane & $\begin{array}{l}\text { Cortex } \\
(300-450 \mu \mathrm{m})\end{array}$ & EGFP (neuron) & Two-photon & $40 x$ & $\begin{array}{l}78 \times 79 \mu \mathrm{m} \\
20 \text { sections with } 1 \mu \mathrm{m} \\
\text { step }\end{array}$ & $-\bar{\sim} \mathrm{h}$ & $\begin{array}{l}\text { Cruz-Martin } \\
\text { et al. (16) }\end{array}$ \\
\hline $\begin{array}{l}\text { CX3CR1- } \\
\text { GFP+/-;Thy1- } \\
\text { YFP }^{+/-} \\
\text {mice }\end{array}$ & - & Thinned & $\begin{array}{l}\text { Ketamine and } \\
\text { xylazine }\end{array}$ & Cortex $(\sim 300 \mu \mathrm{m})$ & $\begin{array}{l}\text { GFP (microglia) } \\
\text { YFP (neuron) } \\
\text { SR101 (astrocyte) } \\
\text { Hoechst (nuclei) }\end{array}$ & Two-photon & $20 \times(N A=1.0)$ & $\begin{array}{l}1,024 \times 1,024 \text { pixel } \\
(0.204 \mu \mathrm{m} / \text { pixel) } \\
34 \text { planes with } 3 \mu \mathrm{m} \\
\text { step }\end{array}$ & $\begin{array}{l}2-3 h \\
-\end{array}$ & $\begin{array}{l}\text { Damisah et al. } \\
\text { (17) }\end{array}$ \\
\hline $\begin{array}{l}\text { CX3CR1-GFP }{ }^{+/-} \\
\text {mice }\end{array}$ & - & Thinned & $\begin{array}{l}\text { Ketamine and } \\
\text { xylazine }\end{array}$ & Cortex $(\sim 200 \mu \mathrm{m})$ & GFP (microglia) & Two-photon & $\begin{array}{l}40 \times(N A=0.8) \\
60 x(N A=0.9 \text { or } \\
1.0)\end{array}$ & 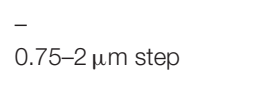 & - & $\begin{array}{l}\text { Davalos et al. } \\
\text { (2) }\end{array}$ \\
\hline $\begin{array}{l}\text { CX3CR1- } \\
\text { GFP }^{+/-} \text {;Thy1- } \\
\text { YFP }^{+/-} \\
\text {mice }\end{array}$ & - & Thinned & - & Cortex & $\begin{array}{l}\text { GFP (microglia) } \\
\text { YFP (neuron) } \\
\text { Alexa594 (fibrinogen) }\end{array}$ & Multi-photon & $\begin{array}{l}10 \times(\mathrm{NA}=0.4) \\
40 \times(\mathrm{NA}=0.8)\end{array}$ & $\begin{array}{l}- \\
1.0-1.5 \text { or } 3-4 \mu \mathrm{m} \\
\text { step }\end{array}$ & $\begin{array}{l}120-240 \mathrm{~s} \\
30-90 \mathrm{~min}\end{array}$ & $\begin{array}{l}\text { Davalos et al. } \\
\text { (18) }\end{array}$ \\
\hline $\begin{array}{l}\text { CX3CR1-GFP }+/- \\
\text { mice }\end{array}$ & - & Open & $\begin{array}{l}\text { Mixture of } \\
\text { ketamine, xylazine } \\
\text { and acepromazine }\end{array}$ & Spinal cord & $\begin{array}{l}\text { GFP (microglia) } \\
\text { rhodamine dextran } \\
\text { (vessel) }\end{array}$ & Two-photon & - & - & - & $\begin{array}{l}\text { Davalos et al. } \\
\text { (19) }\end{array}$ \\
\hline $\begin{array}{l}\text { CX3CR1-GFP }+/- \\
\text { mice }\end{array}$ & P40-130 & Open & $\begin{array}{l}\text { Pentobarbital } \\
\text { sodium and } \\
\text { methohexital } \\
\text { sodium }\end{array}$ & Spinal cord & GFP (microglia) & Two-photon & $\begin{array}{l}40 x(N A=0.75) \\
20 x(N A=1.0)\end{array}$ & $\begin{array}{l}256 \times 256 \text { or } 1,024 \times \\
1,024 \text { pixel }(0.24-0.72 \\
\mu \mathrm{m} / \text { pixel) } \\
16-24 \text { planes with } \\
1.5-2.0 \mu \mathrm{m} \text { step }\end{array}$ & $\begin{array}{l}1-2 \min \\
-\end{array}$ & $\begin{array}{l}\text { Dibaj et al. } \\
(20)\end{array}$ \\
\hline $\begin{array}{l}\text { WT mice } \\
\text { CX3CR1-GFP }+/- \\
\text { mice }\end{array}$ & $2-4 \mathrm{mo}$ & Thinned & Isoflurane & Cortex & $\begin{array}{l}\text { GFP, OGB-1, Fluo-4, } \\
\text { Isolectin B4 conjugated to } \\
\text { Alexa Fluor } 594 \text { (microglia) }\end{array}$ & Two-photon & $\begin{array}{l}40 \times(N A=0.8) \\
60 x(N A=1.0)\end{array}$ & $\begin{array}{l}- \\
10 \mu \mathrm{m} \text { with } 1 \mu \mathrm{m} \text { step }\end{array}$ & - & $\begin{array}{l}\text { Eichhoff et al. } \\
\text { (21) }\end{array}$ \\
\hline
\end{tabular}


TABLE 1 | Continued

\begin{tabular}{|c|c|c|c|c|c|c|c|c|c|c|}
\hline Animal & Age & Skull & Anesthesia & $\begin{array}{l}\text { Region (depth } \\
\text { from the } \\
\text { surface) }\end{array}$ & Cellular visualization & Microscopy & Objective lens & $\begin{array}{l}\text { Resolution }(x, y) \\
\text { z stack }\end{array}$ & $\begin{array}{l}\text { Interval time } \\
\text { Total time }\end{array}$ & References \\
\hline $\begin{array}{l}\text { CD11b- } \\
\text { CreERT2;R26- } \\
\text { tdTomato;APPPS1 } \\
\text { mice }\end{array}$ & 4, $10 \mathrm{mo}$ & Open & Isoflurane & $\begin{array}{l}\text { Cortex } \\
(200-250 \mu \mathrm{m})\end{array}$ & tdTomato (microglia) & Two-photon & $25 \times(N A=0.95)$ & $\begin{array}{l}0.27 \mu \mathrm{m} / \text { pixel or } 1.49 \\
\mu \mathrm{m} / \text { pixel } \\
-\end{array}$ & $\begin{array}{l}\text { Biweekly or } \\
\text { monthly } \\
1.5 \text { years }\end{array}$ & $\begin{array}{l}\text { Füger et al. } \\
\text { (22) }\end{array}$ \\
\hline $\begin{array}{l}\text { TH-tdTomato } \\
\text { CX3CR1-GFP } \\
\text { mice }\end{array}$ & P56 & Thinned & Isoflurane & Olfactory bullb & $\begin{array}{l}\text { GFP (microglia) } \\
\text { TH neuron (mCherry) }\end{array}$ & Two-photon & $20 \times(N A=1.0)$ & $\begin{array}{l}0.09 \mu \mathrm{m} / \text { pixel or } 0.99 \\
\mu \mathrm{m} / \mathrm{pixel} \\
-\end{array}$ & $\begin{array}{l}30 \mathrm{~s} \\
10 \mathrm{~min}\end{array}$ & $\begin{array}{l}\text { Grier et al. } \\
(23)\end{array}$ \\
\hline $\begin{array}{l}\text { Thy1-YFP } \\
\text { CX3CR1- } 1- \\
\text { EGFP }^{+/-} \\
\text {mice }\end{array}$ & & Thinned & $\begin{array}{l}\text { Ketamine and } \\
\text { xylazine }\end{array}$ & $\begin{array}{l}\text { Cortex }(\sim 100 \mu \mathrm{m} \\
\text { for neuron and } \\
\sim 200 \mu \mathrm{m} \text { for } \\
\text { microglia) }\end{array}$ & $\begin{array}{l}\text { YFP (neuron) } \\
\text { EGFP (microglia) }\end{array}$ & Two-photon & $60 \times(\mathrm{NA}=1.1)$ & $\begin{array}{l}512 \times 512 \text { pixel }(66.7 \\
\times 66.7 \mu \mathrm{m}) \\
0.75 \mu \mathrm{m} \text { step }\end{array}$ & $\begin{array}{l}- \\
\sim 2 \mathrm{~h}\end{array}$ & $\begin{array}{l}\text { Grutzendler } \\
\text { et al. (24) }\end{array}$ \\
\hline $\begin{array}{l}\text { Thy } 1 \text {-YFP+/- mice } \\
\text { (H-line) }\end{array}$ & e 6-7 mo & Open & $\begin{array}{l}\text { Ketamine and } \\
\text { xylazine }\end{array}$ & $\begin{array}{l}\text { Hippocampus } \\
(50 \mu \mathrm{m} \text { below the } \\
\text { pyramidal cell } \\
\text { layer) }\end{array}$ & YFP (neuron) & Two-photon & $16 x(\mathrm{NA}=0.8)$ & $\begin{array}{l}100 \times 100 \mu \mathrm{m}(0.09 \\
\mu \mathrm{m} / \mathrm{pixel}) \\
60 \mu \mathrm{m} \text { with } 1 \mu \mathrm{m} \text { step }\end{array}$ & $\begin{array}{l}4 \text { d interval } \\
-\end{array}$ & Gu et al. (25) \\
\hline $\begin{array}{l}\text { CX3CR1-GFP }+/- \\
\text { mice }\end{array}$ & - & Thinned & - & Cortex & GFP (microglia) & Two-photon & - & $\begin{array}{l}- \\
15 \text { planes with } 2 \mu \mathrm{m} \\
\text { step }\end{array}$ & $\begin{array}{l}4 \mathrm{~min} \\
40 \mathrm{~min}\end{array}$ & $\begin{array}{l}\text { Haynes et al. } \\
\text { (26) }\end{array}$ \\
\hline $\begin{array}{l}\text { mpeg1:GFP } \\
\text { (zebrafish) }\end{array}$ & $4 \mathrm{dpf}$ & - & $0.01 \%$ MS-222 & $\begin{array}{l}\text { Brain } \\
(100-150 \mu \mathrm{m}) \\
\text { trunk }(80-120 \mu \mathrm{m})\end{array}$ & $\begin{array}{l}\text { GFP (microglia) } \\
\text { PI (dead cell) }\end{array}$ & Confocal & - & $\begin{array}{l}- \\
\text { 3.6-6 } 4 \mathrm{~m} \text { step }\end{array}$ & $\begin{array}{l}6 \min \\
-\end{array}$ & $\begin{array}{l}\text { Herzog et al. } \\
\text { (27) }\end{array}$ \\
\hline $\begin{array}{l}\text { CX3CR1- } \\
\text { GFP }^{+/-} ; \text {Cnp- } \\
\text { mEGFP }+/-; P l p- \\
\text { DsRed }{ }^{+/-} \\
\text {mice }\end{array}$ & P30-1,100 & $\begin{array}{l}\text { Thinned or } \\
\text { open }\end{array}$ & - & $\begin{array}{l}\text { Somatosensory } \\
\text { cortex }(\sim 75 \mu \mathrm{m})\end{array}$ & $\begin{array}{l}\text { GFP (microglia) } \\
\text { mEGFP (myelin) } \\
\text { DsRed (oligodendrocyte) }\end{array}$ & $\begin{array}{l}\text { Confocal or } \\
\text { two-photon }\end{array}$ & $20 \times(N A=1.0)$ & - & - & Hill et al. (28) \\
\hline $\begin{array}{l}\text { CX3CR1-GFP }+/- \\
\text { mice }\end{array}$ & 6-10 wo & Thinned & $\begin{array}{l}\text { Awake or mixture } \\
\text { of ketamine and } \\
\text { xylazine or } \\
\text { pentobarbital }\end{array}$ & $\begin{array}{l}\text { Somatosensory } \\
\text { cortex } \\
(50-150 \mu \mathrm{m})\end{array}$ & GFP (microglia) & Two-photon & $20 \times(N A=0.95)$ & $\begin{array}{l}521 \times 521 \text { pixel }(0.38 \\
\mu \mathrm{m} / \text { pixel) } \\
26-37 \text { planes with } \\
1 \mu \mathrm{m} \text { step }\end{array}$ & $\begin{array}{l}30 \mathrm{~s} \\
15-20 \mathrm{~min}\end{array}$ & $\begin{array}{l}\text { Hristovska } \\
\text { et al. (29) }\end{array}$ \\
\hline $\begin{array}{l}\text { NSG-CCR2- } \\
\mathrm{RFP}^{+/-} ; \mathrm{CX} 3 \mathrm{CR} 1- \\
\mathrm{GFP}^{+/-} \\
\text {mice }\end{array}$ & 8-12 wo & - & Isoflurane & Frontal cortex & $\begin{array}{l}\text { GFP (microglia) } \\
\text { RFP (macrophage) } \\
\text { BFP (tumor) }\end{array}$ & Two-photon & $20 \times(N A=0.95)$ & $\begin{array}{l}1,024 \times 1,024 \text { pixel } \\
(0.584 \mu \mathrm{m} / \text { pixel) } \\
7 \text { planes with } 1 \mu \mathrm{m} \\
\text { step }\end{array}$ & - & $\begin{array}{l}\text { Hutter et al. } \\
\text { (30) }\end{array}$ \\
\hline $\begin{array}{l}\text { Thy1-GFP+/- } \\
\text { mice (M-line) }\end{array}$ & - & $\begin{array}{l}\text { Open or } \\
\text { thinned }\end{array}$ & $\begin{array}{l}\text { Ketamine and } \\
\text { xylazine }\end{array}$ & $\begin{array}{l}\text { Somatosensory } \\
\text { cortex }(\sim 100 \mu \mathrm{m})\end{array}$ & GFP (neuron) & Two-photon & $25 \times(N A=1.05)$ & $\begin{array}{l}78 \times 78 \mu \mathrm{m}(0.15 \\
\mu \mathrm{m} / \mathrm{pixel}) \\
0.75 \text { or } 0.5 \mu \mathrm{m} \text { step }\end{array}$ & $\begin{array}{l}90 \min \\
-\end{array}$ & $\begin{array}{l}\text { Isshiki and } \\
\text { Okabe (31) }\end{array}$ \\
\hline $\begin{array}{l}\text { Tg(Apo-E:eGFP) } \\
\text { (zebrafish) }\end{array}$ & $5-8 \mathrm{dpf}$ & - & Awake & - & $\begin{array}{l}\text { GFP (microglia) } \\
\text { OGB-AM }\left(\mathrm{Ca}^{2+}\right)\end{array}$ & $\begin{array}{l}\text { Confocal or } \\
\text { two-photon }\end{array}$ & $40 \times(N A=0.80)$ & $\begin{array}{l}- \\
1 \mu \mathrm{m} \\
\text { step }\end{array}$ & $\begin{array}{l}2-4 \mathrm{~s} \text { or } \\
1.5-5 \mathrm{~min}\end{array}$ & Li et al. (32) \\
\hline
\end{tabular}




\begin{tabular}{|c|c|c|c|c|c|c|c|c|c|c|}
\hline Animal & Age & Skull & Anesthesia & $\begin{array}{l}\text { Region (depth } \\
\text { from the } \\
\text { surface) }\end{array}$ & Cellular visualization & Microscopy & Objective lens & $\begin{array}{l}\text { Resolution }(x, y) \\
\text { z stack }\end{array}$ & $\begin{array}{l}\text { Interval time } \\
\text { Total time }\end{array}$ & References \\
\hline $\begin{array}{l}\text { CX3CR1-GFP }+/- \\
\text { mice }\end{array}$ & $2-3 \mathrm{mo}$ & Open & $\begin{array}{l}\text { Awake or } \\
\text { isoflurane or } \\
\text { ketamine and } \\
\text { xylazine }\end{array}$ & Cortex & GFP (microglia) & Two-photon & $40 x$ & $\begin{array}{l}512 \times 512 \text { pixel }(0.35 \\
\mu \mathrm{m} / \text { pixel }) \\
8 \text { planes with } 2 \mu \mathrm{m} \\
\text { step }\end{array}$ & $\begin{array}{l}1 \mathrm{~min} \\
-\end{array}$ & Liu et al. (33) \\
\hline $\begin{array}{l}\text { Iba1-EGFP+/- } \\
\text { mice }\end{array}$ & P8-10 & Open & $\begin{array}{l}\text { Urethane and } \\
\text { atropine or awake }\end{array}$ & $\begin{array}{l}\text { Cortex } \\
(45-250 \mu \mathrm{m})\end{array}$ & $\begin{array}{l}\text { GFP (microglia) } \\
\text { tdTomato (neuron) } \\
\text { GCaMP6m }\left(\mathrm{Ca}^{2+}\right)\end{array}$ & Two-photon & $25 \times(N A=1.05)$ & $\begin{array}{l}512 \times 512 \text { pixel }(0.099 \\
\mu \mathrm{m} / \text { pixel }) \\
0.5 \mu \mathrm{m} \text { step }\end{array}$ & $\begin{array}{l}5 \mathrm{~min}, 30 \mathrm{~min}-2 \mathrm{~h} \\
\text { or } 1.6 \mathrm{~s}-1 \mathrm{~min}, \\
27 \mathrm{~min} \text { or } 8 \mathrm{~Hz} \text {, } \\
30 \mathrm{~min}\end{array}$ & $\begin{array}{l}\text { Miyamoto } \\
\text { et al. (34) }\end{array}$ \\
\hline $\begin{array}{l}\text { Tg(mpeg1:GAL4, } \\
\text { UAS:mCherry); } \\
\text { rwTg(isl1:GFP); } \\
\text { Tg(- } \\
\text { 3.5ubb:secAnnexin } \\
\text { V-mVenus) } \\
\text { (zebrafish) }\end{array}$ & $2-5 \mathrm{dpf}$ & - & $0.01 \%$ tricaine & Spinal cord & $\begin{array}{l}\text { mCherry (microglia) } \\
\text { GFP (neuron) } \\
\text { mVenus (AnnexinV) }\end{array}$ & Confocal & $\begin{array}{l}10 \times(\mathrm{NA}=0.3), \\
40 \times(\mathrm{NA}=0.8), \\
63 \times(\mathrm{NA}=0.9)\end{array}$ & $\begin{array}{l}- \\
10-15 \text { planes with } \\
1-2 \mu \mathrm{m} \text { step }\end{array}$ & $3-8 \min$ & $\begin{array}{l}\text { Morsch et al. } \\
\text { (35) }\end{array}$ \\
\hline $\begin{array}{l}\text { CX3CR1-GFP }+/- \\
\text { mice }\end{array}$ & $1.5-15 \mathrm{mo}$ & Thinned & Isoflurane & Cortex $(75 \mu \mathrm{m})$ & GFP (microglia) & Two-photon & - & $\begin{array}{l}- \\
15-25 \text { planes with } \\
1-2 \mu \mathrm{m} \text { step }\end{array}$ & $\begin{array}{l}20-45 \mathrm{~s} \\
\text { Several hours }\end{array}$ & $\begin{array}{l}\text { Nimmerjahn } \\
\text { et al. (1) }\end{array}$ \\
\hline $\begin{array}{l}\text { CX3CR1-GFP }+/- \\
\text { mice }\end{array}$ & $\begin{array}{l}2-4,9-11 \\
18-21 \mathrm{mo}\end{array}$ & Thinned & Isoflurane & $\begin{array}{l}\text { Cortex } \\
(80-100 \mu \mathrm{m})\end{array}$ & $\begin{array}{l}\text { GFP (microglia) } \\
\text { Oregon Green } 488\left(\mathrm{Ca}^{2+}\right)\end{array}$ & Two-photon & $40 \times(N A=0.80)$ & - & $\begin{array}{l}4 \text { frames } / \mathrm{s} \text { or } 10 \\
\text { frames } / \mathrm{s} \text { or } 30 \mathrm{~s} \text {, } \\
20 \mathrm{~min}\end{array}$ & $\begin{array}{l}\text { Olmedillas Del } \\
\text { Moral et al. } \\
\text { (36) }\end{array}$ \\
\hline $\begin{array}{l}\text { CX3CR1 }{ }^{\text {CreER/+: }} \\
\text { Thy1 YFP-H mice }\end{array}$ & P19-34 & Thinned & $\begin{array}{l}\text { Ketamine and } \\
\text { xylazine }\end{array}$ & $\begin{array}{l}\text { Motor cortex } \\
(\sim 100 \mu \mathrm{m})\end{array}$ & YFP (neuron) & Two-photon & $60 \times(\mathrm{NA}=1.1)$ & - & $\begin{array}{l}4 d \\
-\end{array}$ & $\begin{array}{l}\text { Parkhurst } \\
\text { et al. (37) }\end{array}$ \\
\hline $\begin{array}{l}\text { ApoE-GFP;NBT- } \\
\text { DsRed } \\
\text { (zebrafish) }\end{array}$ & $3 \mathrm{dpf}$ & - & $0.01 \%$ tricaine & - & $\begin{array}{l}\text { GFP (microglia) } \\
\text { DsRed (neuron) } \\
\text { LysoTracker DND-9 } \\
\text { (lysosome) }\end{array}$ & Confocal & $40 \times(N A=1.2)$ & $\begin{array}{l}- \\
4 \text { stacks spanning } \\
10 \mu \mathrm{m}\end{array}$ & - & Peri et al. (38) \\
\hline $\begin{array}{l}\text { PC::G5-tdTomato } \\
\text { mice }\end{array}$ & $2-4 \mathrm{mo}$ & Thinned & Isoflurane & $\begin{array}{l}\text { Visual or } \\
\text { somatosensory } \\
\text { cortex }(\sim 100 \mu \mathrm{m})\end{array}$ & $\begin{array}{l}\text { tdTomato (microglia) } \\
\text { GCaMP5G }\left(\mathrm{Ca}^{2+}\right)\end{array}$ & Two-photon & $16 \times(N A=0.8)$ & $\begin{array}{l}512 \times 512 \text { or } 1,024 \times \\
1,024 \text { pixel }\end{array}$ & $\begin{array}{l}0.125 \text { frames/s or } \\
0.5 \mathrm{~Hz} \\
-\end{array}$ & $\begin{array}{l}\text { Pozner et al. } \\
\text { (39) }\end{array}$ \\
\hline $\begin{array}{l}\text { B6.Cg-Tg(Thy1- } \\
\text { YFP)HJrs/J mice } \\
\text { (\#003782, JaxLab) }\end{array}$ & 4-10 wo & Open & $\begin{array}{l}\text { Isoflurane and } \\
\text { ketamine }\end{array}$ & $\begin{array}{l}\text { Somatosensory } \\
\text { cortex }\end{array}$ & YFP (neuron) & Two-photon & $25 \times(N A=1.05)$ & $\begin{array}{l}166.7 \times 166.7 \mu \mathrm{m} \\
(512 \times 512 \text { or } 800 \times \\
800 \text { pixel) } \\
30-70 \mu \mathrm{m} \text { with } 1 \mu \mathrm{m} \\
\text { step }\end{array}$ & $\begin{array}{l}24 \mathrm{~h} \\
-\end{array}$ & $\begin{array}{l}\text { Pryazhnikov } \\
\text { et al. (40) }\end{array}$ \\
\hline $\begin{array}{l}\text { CX3CR1- } \\
\text { GFP }^{+/-} \text {;Thy1- } \\
\text { YFP }^{+/-} \\
\text {mice }\end{array}$ & 3-17 wo & Open & $\begin{array}{l}\text { Awake or } \\
\text { dexmedetomidine } \\
\text { and midazolam }\end{array}$ & Cortex & $\begin{array}{l}\text { GFP (microglia) } \\
\text { YFP (neuron) }\end{array}$ & Two-photon & $20 \times(N A=0.95)$ & $\begin{array}{l}- \\
1 \mu \mathrm{m} \mathrm{step}\end{array}$ & $\begin{array}{l}5 \mathrm{~min} \\
1 \mathrm{~h}\end{array}$ & $\begin{array}{l}\text { Stowell et al. } \\
(41)\end{array}$ \\
\hline $\begin{array}{l}\text { CX3CR1-GFP }+/- \\
\text { mice }\end{array}$ & $3-4 \mathrm{mo}$ & Open & $\begin{array}{l}\text { Awake or } \\
\text { isoflurane or } \\
\text { ketamine }\end{array}$ & $\begin{array}{l}\text { Cortex } \\
(100-150 \mu \mathrm{m})\end{array}$ & GFP (microglia) & Two-photon & $20 \times(N A=1.00)$ & $\begin{array}{l}512 \times 512 \text { pixel }(0.77 \\
\mu \mathrm{m} / \text { pixel) } \\
6 \text { planes with } 2 \mu \mathrm{m} \\
\text { step }\end{array}$ & $\begin{array}{l}20 \mathrm{~s} \\
33 \mathrm{~min}\end{array}$ & Sun et al. (42) \\
\hline
\end{tabular}


TABLE 1 | Continued

\begin{tabular}{|c|c|c|c|c|c|c|c|c|c|c|}
\hline Animal & Age & Skull & Anesthesia & $\begin{array}{l}\text { Region (depth } \\
\text { from the } \\
\text { surface) }\end{array}$ & Cellular visualization & Microscopy & Objective lens & $\begin{array}{l}\text { Resolution }(x, y) \\
\text { z stack }\end{array}$ & $\begin{array}{l}\text { Interval time } \\
\text { Total time }\end{array}$ & References \\
\hline $\begin{array}{l}\text { CX3CR1-GFP+/- } \\
\text { mice, } \\
\text { CX3CR1CreER- } \\
\text { eYFP mice, and } \\
\text { Rosa-CAG-LSL- } \\
\text { eYFP-WPRE } \\
\text { mice }\end{array}$ & 2-5 mo & Open & Isoflurane & $\begin{array}{l}\text { Somatosensory } \\
\text { cortex } \\
(50-100 \mu \mathrm{m})\end{array}$ & $\begin{array}{l}\text { GFP, YFP (microglia) } \\
\text { Evans } \\
\text { lue,Rhodamine-dextran } \\
\text { (vessel) }\end{array}$ & Multi-photon & $40 \times(\mathrm{NA}=0.8)$ & $\begin{array}{l}800 \times 800 \text { pixel }(0.18 \\
\mu \mathrm{m} / \text { pixel) } \\
-\end{array}$ & $\begin{array}{l}4 \text { min } \\
40-60 \text { min }\end{array}$ & $\begin{array}{l}\text { Taylor et al. } \\
\text { (43) }\end{array}$ \\
\hline $\begin{array}{l}\text { CX3CR1- } \\
\text { GFP }^{+/-} \text {;Thy1- } \\
\text { YFP+/- }^{+1} \\
\text { mice }\end{array}$ & P28-39 & Thinned & - & $\begin{array}{l}\text { Primary visual } \\
\text { cortex }(50 \mu \mathrm{m})\end{array}$ & $\begin{array}{l}\text { GFP (microglia) } \\
\text { YFP (neuron) }\end{array}$ & Two-photon & $20 \times(N A=0.95)$ & $\begin{array}{l}- \\
1 \mu \mathrm{m} \mathrm{step}\end{array}$ & $\begin{array}{l}5 \mathrm{~min} \\
30 \mathrm{~min}-2 \mathrm{~h}\end{array}$ & $\begin{array}{l}\text { Tremblay } \\
\text { et al. (44) }\end{array}$ \\
\hline $\begin{array}{l}\text { Rosa26-CAG- } \\
\text { LSL-GCaMP6s } \\
\text { mice, Rosa26- } \\
\text { CAG-LSL-Lck- } \\
\text { GCaMP6f mice, } \\
\text { and } \\
\text { CX3CR1 CreER-eYFP } \\
\text { mice }\end{array}$ & $3-5 \mathrm{mo}$ & Open & Awake & $\begin{array}{l}\text { Somatosensory } \\
\text { cortex (55-80 } \mu \mathrm{m})\end{array}$ & $\begin{array}{l}\text { GCaMP6s, GCaMP6f } \\
\left(\mathrm{Ca}^{2+}\right) \\
\text { GFP (microglia) }\end{array}$ & Two-photon & $16 x(\mathrm{NA}=0.8)$ & $\begin{array}{l}512 \times 512 \text { pixel }(300 \times \\
300 \mu \mathrm{m})\end{array}$ & $\begin{array}{l}1 \mathrm{~s} \\
-\end{array}$ & $\begin{array}{l}\text { Umpierre } \\
\text { et al. (45) }\end{array}$ \\
\hline $\begin{array}{l}\text { Iba1- } \\
\text { EGFP }^{+/-} ; \text {Thy1- } \\
\text { GFP }^{+/-} \\
\text {mice }\end{array}$ & $6-10$ wo & Thinned & $\begin{array}{l}\text { Ketamine and } \\
\text { xylazine }\end{array}$ & $\begin{array}{l}\text { Cortex } \\
(100-250 \mu \mathrm{m})\end{array}$ & $\begin{array}{l}\text { GFP (microglia) } \\
\text { YFP (neuron) }\end{array}$ & Two-photon & $60 \times(\mathrm{NA}=1.1)$ & $\begin{array}{l}- \\
40-50 \text { planes with } \\
0.5 \mu \mathrm{m} \text { step }\end{array}$ & $\begin{array}{l}0.3-1.0 \mathrm{~s} \\
-\end{array}$ & Wake et al. (3) \\
\hline $\begin{array}{l}\text { Thy1-YFP+/- } \\
\text { mice (H-line) }\end{array}$ & $2-7 \mathrm{mo}$ & $\begin{array}{l}\text { Open or } \\
\text { thinned }\end{array}$ & - & $\begin{array}{l}\text { Barrel cortex } \\
(0-100 \mu \mathrm{m})\end{array}$ & YFP (neuron) & Two-photon & $60 \times(N A=0.9)$ & - & - & Xu et al. (5) \\
\hline $\begin{array}{l}\text { Tg(- } \\
\text { 2.8elavl3:eGFP; } \\
\text { coro1a:DsRedx) } \\
\text { (zebrafish) }\end{array}$ & $1-5 \mathrm{dpf}$ & - & $\begin{array}{l}\text { Awake or } 0.01 \% \\
\text { tricaine }\end{array}$ & - & $\begin{array}{l}\text { DsRed-Express (microglia) } \\
\text { GFP (neuron) }\end{array}$ & Confocal & $20 x$ & $\begin{array}{l}\text { - } \\
\text { 40-50 planes with } \\
3 \mu \mathrm{m} \text { step }\end{array}$ & $\begin{array}{l}3-5 \min \\
-\end{array}$ & Xu et al. (53) \\
\hline $\begin{array}{l}\text { Thy1-YFP+/- } \\
\text { mice (H-line) } \\
\text { CX3CR1- } \\
\text { EGFP+/- } \\
\text { mice }\end{array}$ & - & Thinned & $\begin{array}{l}\text { Ketamine and } \\
\text { xylazine }\end{array}$ & $\begin{array}{l}\text { Cortex }(\sim 100 \mu \mathrm{m} \\
\text { for neuron and } \\
\sim 200 \mu \mathrm{m} \text { for } \\
\text { microglia) }\end{array}$ & $\begin{array}{l}\text { YFP (neuron) } \\
\text { EGFP (microglia) }\end{array}$ & Two-photon & $60 \times(\mathrm{NA}=1.1)$ & $\begin{array}{l}512 \times 512 \text { pixel }(66.7 \\
\times 66.7 \mu \mathrm{m}) \\
0.75 \mu \mathrm{m} \text { step }\end{array}$ & $\begin{array}{l}- \\
\sim 2 \mathrm{~h}\end{array}$ & $\begin{array}{l}\text { Yang et al. } \\
(46)\end{array}$ \\
\hline $\begin{array}{l}\text { Thy1-YFP+/- } \\
\text { mice } \\
\text { Thy1-GFP+/- } \\
\text { mice }\end{array}$ & $1 \mathrm{mo}$ & Thinned & $\begin{array}{l}\text { Ketamine and } \\
\text { xylazine }\end{array}$ & $\begin{array}{l}\text { Motor cortex } \\
(100-200 \mu \mathrm{m})\end{array}$ & YFP or GFP (neuron) & Two-photon & $60 \times(\mathrm{NA}=1.1)$ & $\begin{array}{l}70 \times 70 \mu \mathrm{m}(512 \times \\
512 \text { pixels }) \\
9 \text { planes with } 0.7 \mu \mathrm{m} \\
\text { step }\end{array}$ & - & Yu et al. (47) \\
\hline
\end{tabular}

mo, month-old; dpf, days post-fertilization; wo, week-old; P, post-natal day; -, not available. 
life. The authors also crossed CD11b-CreERT2;R26-tdTomato mice with APP/PS1 mice and examined microglia around the $A \beta$ plaques (between 4 and 6 months of age). The rate of proliferation and disappearance of microglia around $A \beta$ plaques approximately doubled (20\%).

\section{Microglial Contact to Other Type of Cells}

One of the most important things that cannot be revealed without live imaging is how microglia interact with other cell types. By observing this interaction, we can discover new phenomena and get ideas for examining cell-cell signaling. In a report by Nimmerjahn et al. (1), the authors provided quantitative data on the process dynamics of microglia and even mentioned their interactions with other cell types. First, the authors labeled astrocytes, one of the major glial cells, with the red fluorescent dye sulforhodamine 101 (SR101) and showed that astrocytes, in contrast to microglia, showed virtually no change in morphology of their soma and primary processes. However, it should be noted that SR101 does not label the fine, distal astrocytic processes which are motile and only the proximal branches are labeled. They also captured the microglia coming into contact with the area where the SR101 signal was missing, presumably the cell bodies of the neurons, and with the area surrounding the astrocytes, presumably the blood vessels, which are surrounded by processes of the astrocytes. When the blood-brain barrier was disrupted by laser irradiation, microglial processes accumulated in the irradiated area, suggesting that microglia may also interact with blood vessels.

The improved imaging resolution has enabled real-time observation of microstructures such as microglial filopodia and synapses. Wake et al. performed in vivo two-photon imaging of the sensory or visual cortex in mice (3). They found that microglia make contact with axonal boutons and dendritic spines. It was shown that microglial contact with synapses increased with elevated neural activity by manipulating neural activity through visual stimulation and thermoregulation in mice. Furthermore, the duration of microglial contact with boutons was prolonged after the induction of ischemia, and more than half of the contacted boutons were lost. These results indicate that microglia may monitor synapses by contact and remove abnormal synapses. These results suggest that the ramified form of microglia is suitable for monitoring synapses.

Tremblay et al. also focused on the synaptic monitoring by microglia and performed in vivo two-photon imaging of microglia and dendrites in the visual cortex (44). When mice were transferred from dark to light environments to increase neural activity, microglial motility increased. Electron microscopy revealed that microglial contact with synapses was increased in mice transferred from dark to light environments. Furthermore, live imaging confirmed that the size of the spine increased during microglial contact and decreased after contact. Spines with microglial contact had a higher rate of subsequent disappearance than spines without contact, suggesting that microglia are responsible for synaptic removal. The involvement of microglia in synapse elimination predicted from the work of Wake et al. (3) and Tremblay et al. (44) using in vivo live imaging was later proved histochemically by the work of Paolicelli et al.
(57) and Schafer et al. (58) who found phagocytic inclusions containing synaptic elements in microglia.

It had also been suggested that microglia modulate synapse formation through the release of BDNF (37), but it remained unclear whether microglial contact with synapses is important for synapse formation. To test that point, Miyamoto et al. performed in vivo multiphoton imaging of layers II and III of the sensory cortex of post-natal (P) 8 to 10-day-old mice, where synaptogenesis is active (34). The formation rate of filopodia was significantly higher in dendritic shafts contacting microglia than in areas without microglia. On the other hand, administration of minocycline, a derivative tetracycline that inhibits proinflammatory response of microglia, did not change the frequency of microglial contact with the dendrites but decreased the probability of filopodia formation. The filopodia formation rate was higher when the microglial contact with dendrites was accompanied by a local increase in $\mathrm{Ca}^{2+}$ concentration on the dendrites. Furthermore, removal of microglia by the Dox system during P5-11 reduced the number of functional synapses, indicating the need for microglia in synapse formation. The authors suggested that microglial state is important for the increase in $\mathrm{Ca}^{2+}$ concentration and subsequent spine formation in dendrites on contact because minocycline reduced the expression of the $\mathrm{Ca}^{2+}$-binding protein Ibal mRNA in microglia.

Together, in vivo live imaging studies of microglia-synapse interactions have provided direct evidence that microglia regulate not only synapse removal, but also synapse formation.

Stowell et al. examined the effect of one of the major neurotransmitters, norepinephrine, on microglia-synapse interaction (41). Pharmacological experiments showed that norepinephrine caused microglial process retraction and inhibition of bulbous tip formation by activating $\beta 2$-adrenoceptors expressed in microglia. Furthermore, activation of $\beta 2$-adrenoceptors inhibited ocular dominance in the visual cortex due to monocular shielding and reduced the number of microglial contacts with dendritic spines. These results indicate that $\beta 2$-adrenergic receptordependent microglial contact with the spine may modulate synaptic plasticity.

There are numerous reports of microglia interacting with neurons in response to neural activity, and live imaging studies have been useful in targeting this relationship. Performing in vivo imaging of zebrafish, Li et al. presented an important finding that microglia can both monitor and manipulate neural activity (32). When glutamate uncaging increased the neural activity, microglial processes were attracted toward the active neurons. In doing so, bulbous tips were formed at the tips of microglial processes. Furthermore, in combination with $\mathrm{Ca}^{2+}$ imaging, it was shown that neural activity was reduced following microglial contact. Visualization of microglial Rac using the FRET system further revealed that Rac activity was increased at the microglial process tip as neural activity increased, indicating that this is required for microglial contact to neurons and the formation of a bulbous tip.

Badimon et al. showed that microglia reduce neural activity via the release of adenosine (13). Live imaging of microglia, neuronal axons, and bouton-like structures revealed that 
increased neural activity via the DREADD system promotes microglial process extension via activation of $\mathrm{P} 2 \mathrm{Y} 12$.

\section{Phagocytosis}

Since the persistence of dead cells in the brain parenchyma threatens the homeostasis of brain functions, it is important to elucidate the mechanism of dead cell removal by microglia. Peri et al. performed in vivo live imaging of zebrafish larvae and observed microglial motility (38) to examine the involvement of microglia in the removal of dead cells. Animals knocked out for v0-ATPase a1, which encodes a component of the vacuolar ATPase (V-ATPase), a multisubunit enzyme that mediates the acidification of eukaryotic intracellular organelles, showed reduced digestion of dead cells incorporated into microglia. In addition, phagosomes incorporating dead cells fused with each other during the digestion process. Furthermore, knocking out v0-ATPase al also inhibited the fusion of phagosomes and lysosomes, i.e., the formation of phagolysosomes. This study is impactful in that it unveils the process of digestion of dead cells by microglia and shows that microglia have the ability to not only take in dead cells but also digest them.

Morsch et al. conducted live imaging of spinal cord of zebrafish and showed microglial migration toward and uptake of irradiated neurons upon induction of neuronal cell death by UV irradiation (35). In combination with AnnexinV-mVenus, it was revealed that irradiated neurons underwent apoptosis after being taken up by microglia. Furthermore, the morphology of the microglia changed to an amoeboid shape during neuronal phagocytosis and returned to a stellate morphology after the digestion of neurons. The authors also compared other parameters, such as migration speed and microglial size.

Traumatic brain injury (TBI) also causes pronounced neuronal cell death. Microglia remove dead cells through phagocytosis, but it is not clear whether this phenomenon is protective or damaging to the brain. Herzog et al. performed live imaging of juvenile zebrafish and confirmed that microglia migrate to the injury site within minutes after TBI and phagocytose dead cells (27). In addition, the KO of P2Y12, which is necessary for microglial migration to the injury site, and inhibition of the phosphatidylserine (PS) receptor BAI1 reduced microglial phagocytosis of dead cells and accelerated subsequent secondary cell death in the injury site. These results suggest that the removal of dead cells by microglia is neuroprotective.

Damisah et al. observed the response of microglia and astrocytes to dead neurons in live imaging using photochemical techniques to induce apoptosis in single cell (17). Microglia and astrocytes were observed in separate mice; while microglia phagocytosed cell bodies and proximal dendrites, astrocytes phagocytosed distal dendrites and debris. The authors showed that knocking out the receptor tyrosine kinase Mertk delayed the recognition of dead cells by microglia. In microglia-removed mice, multiple astrocytes around dead cells cooperated in the phagocytosis of cell bodies. This suggests that astrocytes function in a supportive manner for microglia in the phagocytosis of dead cells. Further simultaneous live imaging of microglia and astrocytes is needed to understand the interaction of the two major phagocytes in the brain.
Abiega et al. examined the effect of neuronal hyperexcitability on the clearance of apoptotic cells by microglia (11). Twentyfour hours after KA administration to the hippocampus, process motility (velocity) of cortical microglia decreased. In addition, using immunostaining, FACS and live imaging of acute slices, the authors found that ATP released from hyperexcitable neurons masked the eat-me signal from apoptotic cells, which inhibited phagocytosis of apoptotic cells by microglia. Furthermore, the delayed clearance of apoptotic cells exacerbated the inflammatory response, suggesting that microglial clearance of apoptotic cells is important for maintaining brain homeostasis in the epileptic brain. However, even though neuronal death and microglial phagocytosis of dead cells were prominent in the dentate gyrus and hippocampus, the in vivo live imaging in this study was performed in the cortex, not the hippocampus, highlighting the technical difficulty of imaging deep brain regions.

Grier et al. investigated the possibility that neural activity mediates phagocytosis by microglia in the mammalian olfactory bulb where the lifelong activity-dependent plasticity occurs (23). Dopaminergic neurons in the glomerular layer are particularly plastic, with a sharp decrease in tyrosine hydroxylase expression levels and dopamine production, followed by a decrease in the number of dopaminergic neurons upon blockade of sensory input $(59,60)$. The authors performed in vivo live imaging and found that the blockade of sensory input after nasal obstruction resulted in morphological change of microglia (increased perimeter length) and an increased change rate of perimeter length (23). These results suggest that the reduced neural activity caused by the blockade of sensory input increases the frequency of microglial process extension and retraction. Although not through live imaging, in the nasal obstruction group, the microglia appeared to cover the cell bodies of the dopaminergic neurons, some of which were completely incorporated into the microglia. It was also shown that the synapses of dopaminergic neurons were incorporated into the microglia. These results indicate that the activity-dependent plasticity of the olfactory bulb may be regulated by microglia.

Myelin, which covers axons and controls the velocity of nerve conduction, is also a highly plastic structure that should be studied to further elucidate the interaction between axons and microglia. Although there have been few reports of in vivo live imaging of myelin at present, Hill et al. successfully observed stable myelin in label-free, in vivo live imaging in genetically engineered mice with fluorescently labeled myelin (28). The authors found that the production of oligodendrocytes and the structural plasticity of myelin occur throughout life. They also showed that cell death of oligodendrocytes and myelin degradation occur in old mice. Furthermore, live imaging of mice in which myelin, oligodendrocytes, and microglia were fluorescently labeled revealed that myelin debris produced in old mice is removed by microglia via phagocytosis.

Recently, it has been suggested that microglia also phagocytose tumor cells. Glioblastoma multiforme is a malignant brain tumor and is considered incurable. Tumor-associated macrophages and microglia (TAMs) are major cell types in tumorigenesis and have been shown to promote tumor growth. Therefore, it has been hypothesized that regulating TAM function might conversely 
inhibit tumor growth. Hutter et al. previously suggested that suppressing SIRP $\alpha$-CD47 signaling, a "don't eat me" signal, and promoting tumor phagocytosis by TAM could treat a variety of tumors (61). However, this antitumor effect has been thought to be largely due to macrophages infiltrating from the periphery, and the contribution of brain-resident microglia has not been clarified. In 2019, Hutter et al. attempted to clarify this point by using mice that can distinguish between microglia and macrophages (30). The authors found that CD47 inhibition also promoted tumor phagocytosis by microglia, and in vivo live imaging showed that CD47 inhibition reduced the number of microglial processes, increased process straightness, and reduced the speed of process extension and retraction. These changes in microglial morphology and motility indicated increased microglial contact with tumor cells.

\section{Second Messenger Signaling in Microglia}

The ability to observe second messenger signaling within microglia in real time would reveal what molecules are involved in microglial surveillance and directed movement. Such studies would be a first step toward modulating brain function through microglial regulation. Intracellular $\mathrm{Ca}^{2+}$ dynamics in microglia had been difficult to observe because of the difficulty in efficiently introducing $\mathrm{Ca}^{2+}$ indicator and adeno-associated viruses into microglia, but Eichhoff et al. succeeded in visualizing microglial $\mathrm{Ca}^{2+}$ dynamics for the first time (21). The authors loaded microglia with a calcium indicator, Oregon green BAPTA 1 (OGB-1). In microglia, almost no spontaneous $\mathrm{Ca}^{2+}$ fluctuations or $\mathrm{Ca}^{2+}$ response to increased activity of adjacent neurons, which was induced by bicuculline, was observed. On the other hand, physical damage by electrodes to neurons increased the $\mathrm{Ca}^{2+}$ concentration in nearby microglia. It was also suggested that the increase in $\mathrm{Ca}^{2+}$ in microglia was due to the activation of the ATP receptor P2Y. Furthermore, the latency from neuronal damage to $\mathrm{Ca}^{2+}$ elevation was significantly shorter in microglia than that in astrocytes, suggesting that fluctuations in intracellular $\mathrm{Ca}^{2+}$ concentration underlie the agile response of microglia to tissue damage.

Pozner et al. monitored the intracellular $\mathrm{Ca}^{2+}$ concentration by GCaMP5G while observing microglial morphology with tdTomato using the PC::G5-tdT mouse line (39). Spontaneous increases in $\mathrm{Ca}^{2+}$ concentrations were almost non-existent, but the frequency of elevated $\mathrm{Ca}^{2+}$ concentrations increased $\sim 8$-fold when the microglia were stimulated by LPS. This increase in $\mathrm{Ca}^{2+}$ concentration was observed simultaneously in several microglia. Furthermore, the rates of process extension and retraction of microglia with elevated $\mathrm{Ca}^{2+}$ concentrations were reduced compared to those of microglia without $\mathrm{Ca}^{2+}$ concentration fluctuations.

As mentioned earlier, observing intracellular $\mathrm{Ca}^{2+}$ concentrations in microglia has been technically challenging. Brawek et al. successfully visualized microglial $\mathrm{Ca}^{2+}$ concentrations (14) using a different method than Eichhoff et al. (21) and Pozner et al. (39). Brawek et al. took advantage of the lack of microRNA-9 expression in microglia to create and apply a lentivirus that expresses the $\mathrm{Ca}^{2+}$-indicator protein Twitch-2B in a microRNA-9-dependent manner. They found that the in vivo quiescent microglia showed stable and low $\mathrm{Ca}^{2+}$ concentrations. Since similar results were obtained in the study by Pozner et al. using different tools, it is likely that there is almost no $\mathrm{Ca}^{2+}$ fluctuation in microglia (at least under physiological conditions). In addition, $\mathrm{Ca}^{2+}$ concentrations were elevated in acute slices and dispersed cultures immediately after excision from the brain. This was accompanied by increased expression levels of CD68 and IL-1 $\beta$, suggesting that intracellular $\mathrm{Ca}^{2+}$ concentration is an indicator of microglial proinflammatory response. The authors also confirmed that in vivo laser-induced tissue damage and ATP injection increased microglial $\mathrm{Ca}^{2+}$ concentrations in microglia, suggesting an association between directed process extension to injured areas and intracellular $\mathrm{Ca}^{2+}$ concentrations.

Olmedillas Del Moral et al. applied single-cell electroporation of the $\mathrm{Ca}^{2+}$ indicator Oregon Green 488 to microglia and observed intracellular $\mathrm{Ca}^{2+}$ concentrations in microglia (36). In 2 to 4 -month-old ("young adult"), 9 to 11-month-old ("middleaged"), and 18 to 21-month-old ("old") mice, the frequency and amplitude of spontaneous $\mathrm{Ca}^{2+}$ concentration increases were found to be highest in middle-aged adults. In addition, the speed of process extension toward ATP increased the most in the old group, but the correlation between distance from the ATP injection site and the process speed was lowest in the old group, indicating that the ATP responsiveness varied. These results indicate that the effect of aging may be different between individual microglia.

Umpierre et al. observed $\mathrm{Ca}^{2+}$ dynamics in microglia of awake mice in 2020 (45). The authors achieved microglia-specific expression of GCaMP using CX3CR1-CreER mice. Awake mice also showed no spontaneous increase in $\mathrm{Ca}^{2+}$ concentration. Interestingly, an increase in $\mathrm{Ca}^{2+}$ with process elongation was confirmed in response to both an increased and decreased neuronal activity. Although the dynamics of $\mathrm{Ca}^{2+}$ in microglia has been observed by various methods, no study has yet addressed the molecular mechanism that control $\mathrm{Ca}^{2+}$ dynamics in microglia.

\section{Response of Microglia to Damage}

Brain injury is often accompanied by inflammation. As immune cells in the brain, microglia may both exacerbate and suppress inflammation. In vivo imaging of microglial dynamics in and around injured sites will highlight the study of microglia as a potential therapeutic target for brain injury and the subsequent brain diseases. Davalos et al. is the first report that succeeded in capturing live ramified microglia in vivo (2). In addition to this observation, the authors examined the changes in microglial dynamics caused by tissue damage using laser irradiation and glass electrodes. Furthermore, through a combination of pharmacological treatments, it was shown that ATP released from the site of injury causes microglial process extension via activation of purinergic $G$ protein-coupled receptors in microglia.

Haynes et al. examined the molecular mechanism of directed movement of microglial processes to the site of injury (26). Using $\mathrm{KO}$ mice, they demonstrated that $\mathrm{P} 2 \mathrm{Y} 12$, which is unique in that it is a Gi-type receptor among mostly Gq-type P2Y 
receptors, is required for process extension toward the site of injury. Interestingly, knocking out P2Y12 did not affect the basic surveillance by microglia. Therefore, this study is significant in that it shows that directed process extension to the injury site and surveillance may be regulated by different molecular mechanisms. In the same paper, the authors also performed live imaging of acute slices and showed that P2Y12 expression levels were reduced in correlation with microglial state change.

In the white mater of the spinal cord, the induction of microglial processes at the site of injury was also tested (20). The results showed that elevated ATP and NO levels at the site of injury promoted the extension of microglial processes. Stable live imaging of spinal cord was considered to be difficult due to motion artifacts; Davalos et al. established a spinal cord live imaging system that overcame the above problems by increasing the depth of anesthesia and improving the fixation device (18). However, it should be noted that ketamine and xylazine used as anesthesia could affect the motility of microglia.

Davalos et al. investigated the functional changes in microglia that occur in the diseased brain by in vivo live imaging (19). The authors examined the causes of blood-brain barrier (BBB) damage, microglial state change and neurodegeneration in multiple sclerotic brains and the mechanisms by which they cause axonal damage. In addition, in vivo live imaging revealed that microglial accumulation and myelin shedding occurred before the manifestation of paralysis, a symptom of multiple sclerosis. Furthermore, inhibition of fibrinogen formation by the anticoagulant lepirudin, genetic removal of fibrinogen, and removal of the binding site of fibrinogen to CD11b/CD18 (Fib-/-, Fib/390-396A mice) inhibited the perivascular accumulation of microglia and axonal damage. This study reaffirms the importance of live imaging because this technique unveiled the temporal relationship between microglial accumulation and state change, both of which are causes of multiple sclerosis.

Taylor et al. examined the effect of type I diabetes on the repair of damaged blood vessels by microglia (43). In a mouse model of diabetes, laser irradiation did not cause migration of microglia to the damaged vessels. And the loss of vascular repair by microglia exacerbated secondary vascular leakage, suggesting that microglia are important for the suppression of vascular damage. Furthermore, they found that an increase in IFN- $\gamma$ levels in the blood of a mouse model of obese reduced the expression level of P2Y12 in microglia and suppressed the migration of microglia to damaged blood vessels. Since live imaging of intact blood vessels can only be performed in vivo, in vivo live imaging may be the most suitable method to verify the relationship between vascular injury and microglia.

\section{Achievement and Limitation of in vivo Live Imaging}

In summary, in vivo imaging studies have revealed the dynamics of ramified microglia and contributed to our understanding of the dynamics and significance of microglial motility. For example, it was revealed that microglia could migrate long distance and intracellular $\mathrm{Ca}^{2+}$ activity of microglia was clarified.
Also, it was shown that microglia change their dynamics in response to various transmitters, neural activity, injury, and interaction between other cell types.

It is expected that advances in genetic modification and imaging technology will further refine in vivo live imaging methods for observing intact microglial dynamics, but various technical limitations should not be overlooked at this point. First, most of the live imaging in the studies described in section In vivo Live Imaging (see Table 1 for Experimental Conditions) was performed in the vicinity of the brain surface, which highlights the difficulty of deep brain imaging. The cortical area is a good place to test the relationship between neural activity and microglial dynamics, as well as the relationship between animal behavior and microglial dynamics, since neural activity can be altered by the introduction of sensory stimuli such as visual and auditory stimuli. Live imaging of microglia in deeper brain regions such as the hippocampus and amygdala, which control learning, memory, and emotions, may lead to the discovery of region-specificity of microglial motility and new significance of microglial surveillance in brain functions. $\mathrm{Gu}$ et al. showed that in vivo live imaging of the hippocampus is possible by aspiration of the cortex (25). Microglia in the hippocampus have been shown by immunostaining to exhibit morphology such as reduced process length and hypertrophy of the cell body after surgery, but to return to the surveillant state after 10 days. Badimon et al. performed in vivo neuronal calcium imaging in the dorsal striatum using the gradient-index (GRIN) lens (13). Thus, it is expected that live imaging studies of microglia in deep brain regions will be further advanced by using techniques such as the GRIN optics and cortical aspiration, and that details of microglial dynamics related to brain structure and function will be revealed.

Furthermore, it seems difficult to combine in vivo live imaging with the cell function manipulation by pharmacological and optogenetic methods, because the presence of bones in the thinned skull or the presence of glass coverslips in the open skull will limit what can be done from the brain surface.

Problems of in vivo imaging such as limited observation regions, low resolution, and difficulty in stimulation have been improved. Thus, complementary understanding of the data obtained by in vivo imaging and in vitro imaging, which has advantages such as observation at super-resolution level and manipulation at high spatiotemporal resolution, will help us to understand the mechanism underlying microglia-neuron interaction such as synapse elimination (Figure 2).

\section{EX VIVO LIVE IMAGING}

Live imaging of microglia ex vivo has been attempted as a way to overcome technical difficulties in vivo. In section Ex vivo Live Imaging, we will present studies using live imaging of brain slices. Perhaps the most significant advantage of slice imaging is that the structures in the brain (cell layers and projection pathways) are preserved. This is important for validating the direction of microglial migration and helps facilitate the extrapolation of results obtained with slice imaging to in vivo. In the following 


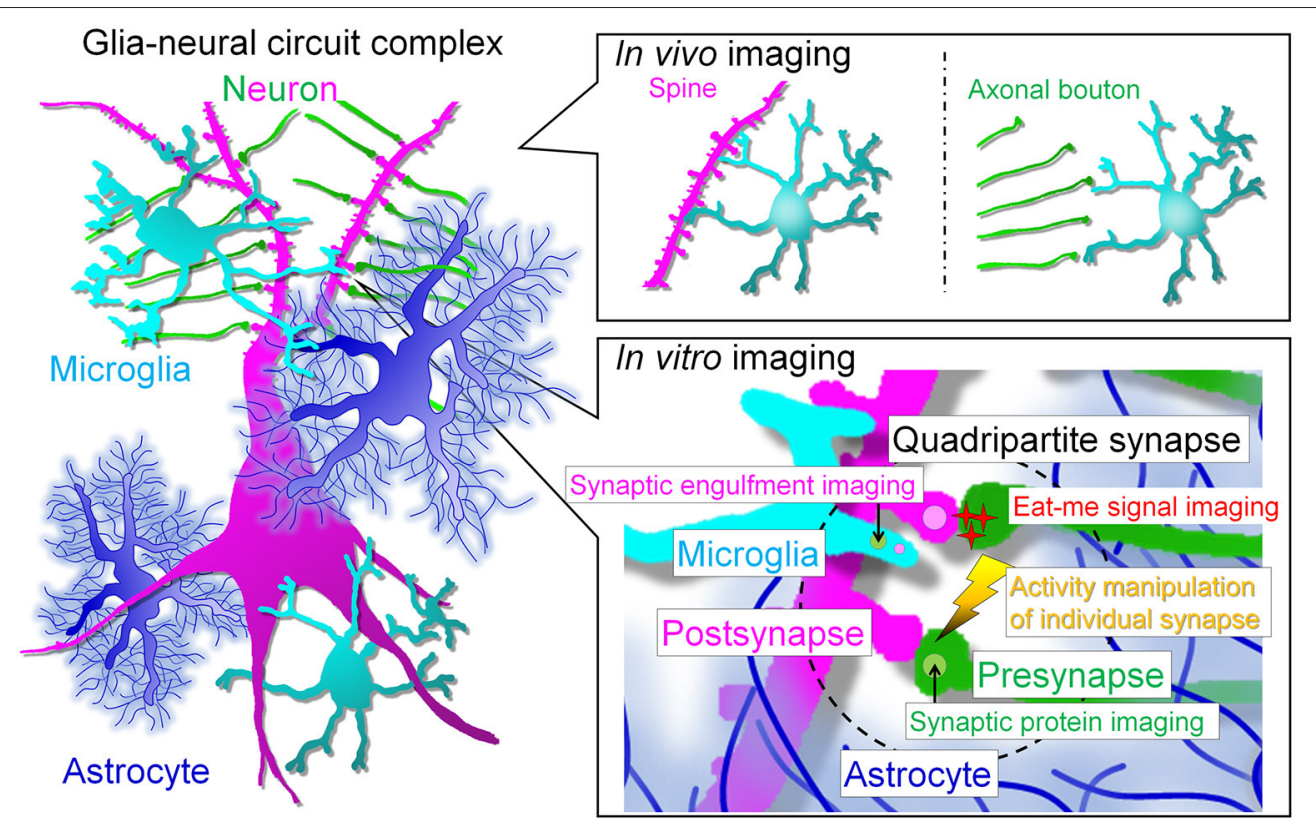

FIGURE 2 | Prospects for live imaging of glial cell-neural circuit complexes. In vivo multiphoton imaging studies have revealed that microglia interact with spines and axonal boutons. In vivo live imaging has greatly advanced the field by revealing the correlation between interactions and neural activity and has enhanced research interest in microglia. However, the next step will be to assess the interaction of each cell type at the synaptic site and the molecular mechanism of the interaction. For this purpose, we need to perform simultaneous high-resolution imaging of the quadripartite synapse, which consists of microglia, astrocytes and pre- and post-synapses. The simultaneous imaging of synapses, neuronal membranes, and microglia will help to answer the remaining major question of whether neurites are snipped off during synaptic phagocytosis. In addition, to understand the molecular mechanism of synaptic competition, it is necessary to control activity at the level of individual synapses. In vitro systems will facilitate live imaging with multiple colors, high resolution, and local stimulation, but a major barrier must be crossed: the establishment of glial cell culture systems that maintain in vivo morphology and gene expression. The realization of such systems is eagerly awaited to clarify the relationship between glia and neurons, especially synapses.

sections, we introduce acute slice imaging, in which sections cut out from the brain are observed immediately after preparation, and cultured slice imaging, in which sections are cultured and observed at any given time.

\section{Acute Slice}

\section{Alterations of Microglial Process Dynamics by ATP and Neurotransmitters}

$\mathrm{Wu}$ et al. examined the molecular mechanisms regulating microglial process motility by the ATP-P2Y receptor signaling pathway (76) (Table 2). Simultaneously, observing microglial motility by confocal microscopy and performing whole-cell patch-clamp recordings of microglia, the authors found that process extension to ATP correlated with the outward potassium current associated with $\mathrm{P} 2 \mathrm{Y}$ receptor activation. It was also shown that both $\mathrm{P} 2 \mathrm{Y}$ receptor activation and outward potassium currents are required for process extension to ATP and basal surveillance. Furthermore, it was shown that the PI3K signaling pathway is important for ATP-induced chemotaxis. Swiatkowski et al. showed that the regulation of process extension by outward potassium currents functions similarly in the microglial response to neuronal damage (75).

Molecules that act in the opposite way to ATP have also been studied. Gyoneva et al. tested the effect of norepinephrine on the motility of microglial processes: bath application of ATP induced microglial process elongation, whereas norepinephrine treatment retracted them (69). Microglia extend their processes to the site of injury in an ATP-P2Y12 signaling-dependent manner. In 2014, Gyoneva et al. tested this by preparing acute slices of mice that had been subjected to inflammatory conditions and performing live imaging (70). In the control group, microglial processes extended to the injured site, but this phenomenon was inhibited when inflammation was induced by prior LPS administration. In addition, MPTP treatment, which induced dopaminergic neuronal death and microglial state change, also inhibited process extension to the injured site. Furthermore, LPS and MPTP treatment increased adenosine A2A receptor expression in microglia and suppressed process extension to the injured site. Because adenosine retracts microglial processes via $\mathrm{A} 2 \mathrm{~A}$ receptors, treatment with preladenant, an antagonist of the $\mathrm{A} 2 \mathrm{~A}$ receptor, along with MPTP treatment, rescued the inhibition of process extension to the injury site.

Dissing-Olesen et al. showed that ATP released from neurons upon NMDAR activation attracts microglial processes (64). Pharmacological experiments showed that the induction of the microglial process was independent of ATP and NO release from Pannexin1 and astrocytic connexins associated with NMDAR activation. The formation of a bulbous tip-like structure at the tip of the microglial process upon ATP treatment indicates that the microglial processes may contact activated neurons 
TABLE 2 | Experimental conditions of live imaging of microglia ex vivo (acute slice).

\begin{tabular}{|c|c|c|c|c|c|c|c|c|c|c|}
\hline Animal & Age & Anesthesia & Region & $\begin{array}{l}\text { Thickness } \\
\text { Depth from the } \\
\text { surface }\end{array}$ & Cellular visualization & Microscopy & Objective lens & $\begin{array}{l}\text { Resolution }(x, y) \\
\text { z stack }\end{array}$ & $\begin{array}{l}\text { Interval time } \\
\text { Total time }\end{array}$ & References \\
\hline $\begin{array}{l}\text { CX3CR1-GFP }+/- \\
\text { mice }\end{array}$ & P30-40 & - & Hippocampus & $\begin{array}{l}350 \mu \mathrm{m} \\
-\end{array}$ & GFP (microglia) & Two-photon & $40 \times(\mathrm{NA}=1.0)$ & $\begin{array}{l}- \\
11-25 \mu \mathrm{m} \text { thick }\end{array}$ & $\begin{array}{l}25 \text { or } 60 \mathrm{~s} \\
\sim 1 \mathrm{~h}\end{array}$ & Avignone et al. (62) \\
\hline $\begin{array}{l}\text { CX3CR1-GFP }+/- \\
\text { mice }\end{array}$ & P45-180 & Isoflurane & Hippocampus & $\begin{array}{l}300 \mu \mathrm{m} \\
150 \pm 25 \mu \mathrm{m}\end{array}$ & GFP (microglia) & Two-photon & $20 x(N A=1.0)$ & $\begin{array}{l}512 \times 512 \text { or } 1,024 \times \\
1,024 \text { pixel } \\
1-2 \mu \mathrm{m} \text { step }\end{array}$ & - & Bernier et al. (9) \\
\hline C57BL/6 mice & $6-8$ wo & - & Coronal section & $\begin{array}{l}300 \mu \mathrm{m} \\
-\end{array}$ & $\begin{array}{l}\text { Alexa 488, } 568 \\
\text { isolectin B4 (microglia) }\end{array}$ & Confocal & $\begin{array}{l}20 x \\
40 x\end{array}$ & $\begin{array}{l}175 \times 175 \mu \mathrm{m} \text { or } 350 \times \\
350 \mu \mathrm{m} \\
40 \mu \mathrm{m}\end{array}$ & $\begin{array}{l}1.5 \mathrm{~min} \\
-\end{array}$ & $\begin{array}{l}\text { Carbonell et al. } \\
\text { (63) }\end{array}$ \\
\hline $\begin{array}{l}\text { CX3CR1-GFP }+/- \\
\text { mice }\end{array}$ & P40-120 & Halothane & Hippocampus & $\begin{array}{l}300 \mu \mathrm{m} \\
150 \pm 25 \mu \mathrm{m}\end{array}$ & GFP (microglia) & Two-photon & $40 \times(\mathrm{NA}=1.0)$ & $\begin{array}{l}512 \times 512 \text { pixel } \\
15 \text { planes with } 2 \mu \mathrm{m} \text { step }\end{array}$ & $\begin{array}{l}1 \mathrm{~min} \\
-\end{array}$ & $\begin{array}{l}\text { Dissing-Olesen } \\
\text { et al. (64) }\end{array}$ \\
\hline $\begin{array}{l}\text { CX3CR1-GFP }+/- \\
\text { mice }\end{array}$ & P5-7 & - & Hippocampus & $\begin{array}{l}400 \mu \mathrm{m} \\
45-60 \mu \mathrm{m}\end{array}$ & GFP (microglia) & $\begin{array}{l}\text { Confocal and } \\
\text { multi-photon }\end{array}$ & $20 x(\mathrm{NA}=0.7)$ & $\begin{array}{l}775 \times 775 \mu \mathrm{m} \\
15 \text { planes with } 3 \mu \mathrm{m} \text { step }\end{array}$ & $\begin{array}{l}3-10 \mathrm{~min} \\
-\end{array}$ & Eyo et al. (65) \\
\hline $\begin{array}{l}\text { CX3CR1- } \\
\text { GFP } \\
\text { YFP }^{+/-} \text {;Thy1- } \\
\text { mice }\end{array}$ & 4 wo & - & Hippocampus & $\begin{array}{l}300 \mu \mathrm{m} \\
50-100 \mu \mathrm{m}\end{array}$ & $\begin{array}{l}\text { GFP (microglia) } \\
\text { YFP (neuron) }\end{array}$ & Two-photon & $40 \times(N A=0.8)$ & - & - & Eyo et al. (66) \\
\hline $\begin{array}{l}\text { CX3CR1-GFP }+/- \\
\text { mice }\end{array}$ & P2-6 & - & Hippocampus & $\begin{array}{l}400 \mu \mathrm{m} \\
45-60 \mu \mathrm{m}\end{array}$ & GFP (microglia) & Confocal & $20 \times(N A=0.7)$ & $\begin{array}{l}775 \times 775 \mu \mathrm{m} \\
15 \text { planes with } 3 \mu \mathrm{m} \text { step }\end{array}$ & $\begin{array}{l}10 \min \\
-\end{array}$ & Eyo et al. (56) \\
\hline $\begin{array}{l}\text { CX3CR1- } \\
\text { GFP }^{+/-} \text {;Thy1- } \\
\mathrm{YFP}^{+/-} \\
\text {mice }\end{array}$ & $3-5$ wo & - & Cortex & $\begin{array}{l}300 \mu \mathrm{m} \\
50-120 \mu \mathrm{m}\end{array}$ & $\begin{array}{l}\text { GFP (microglia) } \\
\text { YFP (neuron) }\end{array}$ & Two-photon & $40 \times(N A=0.8)$ & $\begin{array}{l}- \\
15 \text { planes with } 3 \mu \mathrm{m} \text { step or } \\
10 \text { planes with } 2 \mu \mathrm{m} \text { step }\end{array}$ & $\begin{array}{l}30 \mathrm{~s} \\
-\end{array}$ & Eyo et al. (67) \\
\hline $\begin{array}{l}\text { CX3CR1-GFP }+/- \\
\text { mice }\end{array}$ & $3-8 \mathrm{mo}$ & - & Retina & - & GFP (microglia) & Confocal & $40 \times(\mathrm{NA}=0.8)$ & $\begin{array}{l}512 \times 512 \text { pixel } \\
-\end{array}$ & $\begin{array}{l}10 \mathrm{~s} \\
-\end{array}$ & $\begin{array}{l}\text { Fontainhas et al. } \\
\text { (68) }\end{array}$ \\
\hline $\begin{array}{l}\text { CX3CR1-GFP }+/- \\
\text { mice }\end{array}$ & $1-4 \mathrm{mo}$ & - & Cortex & $200 \mu \mathrm{m}$ & GFP (microglia) & Confocal & $60 x$ & $\begin{array}{l}\text { - } \\
\text { 30-50 planes with } 1 \mu \mathrm{m} \\
\text { step }\end{array}$ & $\begin{array}{l}1 \min \\
-\end{array}$ & Gyoneva et al. (69) \\
\hline $\begin{array}{l}\text { CX3CR1-GFP }+/- \\
\text { mice }\end{array}$ & - & - & Substantia nigra & $200 \mu \mathrm{m}$ & GFP (microglia) & Confocal & $20 x(N A=0.50)$ & $\begin{array}{l}- \\
31 \text { planes with } 1 \mu \mathrm{m} \text { step }\end{array}$ & $\begin{array}{l}30-60 \mathrm{~s} \\
20 \mathrm{~min}\end{array}$ & Gyoneva et al. (70) \\
\hline $\begin{array}{l}\text { SD rats } \\
\text { Iba1-GFP }+/- \text { mice }\end{array}$ & $\begin{array}{l}\text { P12 } \\
\text { P15-27 }\end{array}$ & - & Hippocampus & $\begin{array}{l}300 \mu \mathrm{m} \\
\sim 50-100 \mu \mathrm{m}\end{array}$ & $\begin{array}{l}\text { Isolectin B4-Alexa } 594 \\
\text { or GFP (microglia) }\end{array}$ & Two-photon & $20 \times(N A=1.0)$ & $\begin{array}{l}512 \times 512 \text { pixel }(0.49-0.39 \\
\mu \mathrm{m} / \text { pixel) } \\
21-31 \text { planes with } 2 \mu \mathrm{m} \\
\text { step }\end{array}$ & $60 \mathrm{~s}$ & Madry et al. (52) \\
\hline $\begin{array}{l}\text { MacGreen/cd39-/- } \\
\text { mice }\end{array}$ & - & - & $\begin{array}{l}\text { Somatosensory } \\
\text { cortex }\end{array}$ & $\begin{array}{l}300 \mu \mathrm{m} \\
-\end{array}$ & MacGreen (microglia) & Two-photon & $40 \times(\mathrm{NA}=0.8)$ & $\begin{array}{l}307 \times 307 \mu \mathrm{m} \\
21 \text { planes with } 3 \mu \mathrm{m} \text { step }\end{array}$ & & Matyash et al. (71) \\
\hline $\begin{array}{l}\text { SD rats } \\
\text { Iba1-GFP+/- mice }\end{array}$ & $\begin{array}{l}\text { P12 } \\
\text { P15-27 }\end{array}$ & - & Hippocampus & $\begin{array}{l}300 \mu \mathrm{m} \\
\sim 50-100 \mu \mathrm{m}\end{array}$ & $\begin{array}{l}\text { Isolectin B4-Alexa } 594 \\
\text { or GFP (microglia) }\end{array}$ & Two-photon & $20 x(N A=1.0)$ & $\begin{array}{l}512 \times 512 \text { pixel }(0.49-0.39 \\
\mu \mathrm{m} / \text { pixel) } \\
21-31 \text { planes with } 2 \mu \mathrm{m} \\
\text { step }\end{array}$ & $60 \mathrm{~s}$ & Zhao et al. (72) \\
\hline
\end{tabular}


TABLE 2 | Continued

\begin{tabular}{|c|c|c|c|c|c|c|c|c|c|c|}
\hline Animal & Age & Anesthesia & Region & $\begin{array}{l}\text { Thickness } \\
\text { Depth from the } \\
\text { surface }\end{array}$ & Cellular visualization & Microscopy & Objective lens & $\begin{array}{l}\text { Resolution }(x, y) \\
\text { z stack }\end{array}$ & $\begin{array}{l}\text { Interval time } \\
\text { Total time }\end{array}$ & References \\
\hline $\begin{array}{l}\text { CX3CR1- } \\
\text { GFP }^{+/-} \text {;Thy1- } \\
\text { YFP }^{+1-} \\
\text { mice }\end{array}$ & P28-40 & Isoflurane & Hippocampus & - & $\begin{array}{l}\text { GFP (microglia) } \\
\text { YFP (neuron) }\end{array}$ & Confocal & $40 \times(N A=1.0)$ & $\begin{array}{l}512 \times 512 \text { pixel }(0.39 \\
\mu \mathrm{m} / \text { pixel) } \\
11 \text { planes with } 1 \mu \mathrm{m} \text { step }\end{array}$ & $\begin{array}{l}30 \mathrm{~s} \\
80 \mathrm{~min}\end{array}$ & Pfeiffer et al. (73) \\
\hline $\begin{array}{l}\text { CX3CR1-GFP }+/- \\
\text { mice }\end{array}$ & $3 \mathrm{mo}$ & Euthasol & Spinal cord & $\begin{array}{l}350 \mu \mathrm{m} \\
-\end{array}$ & $\begin{array}{l}\text { GFP (microglia) } \\
\text { Alexa Fluor } 555 \\
\text { (neuron) }\end{array}$ & Two-photon & $25 \times(N A=0.95)$ & $\begin{array}{l}512 \times 512 \text { pixel } \\
31 \text { planes with } 1.5 \mu \mathrm{m} \text { step }\end{array}$ & $\begin{array}{l}30-60 \mathrm{~s} \\
30-60 \mathrm{~min}\end{array}$ & $\begin{array}{l}\text { Rotterman and } \\
\text { Alvarez (74) }\end{array}$ \\
\hline Rats & P3-14 & - & Hippocampus & $\begin{array}{l}400 \mu \mathrm{m} \\
-\end{array}$ & $\begin{array}{l}\text { FITC-IB } \\
4 \\
\text { FITC-IB } \\
4 \\
\text { FITC-IB } \\
4 \\
\text { FITC-IB } 4 \text { (microglia) }\end{array}$ & Confocal & $63 \times(N A=1.2)$ & $\begin{array}{l}512 \times 512 \text { or } 1,024 \times \\
1,024 \text { pixel } \\
8-18 \text { planes }(\sim 60 \mu \mathrm{m})\end{array}$ & $\begin{array}{l}2-5 \min \\
30-90 \min \end{array}$ & Stence et al. (6) \\
\hline $\begin{array}{l}\text { CX3CR1-GFP+/- } \\
\text { mice }\end{array}$ & $3-6$ wo & - & Coronal section & $\begin{array}{l}300 \mu \mathrm{m} \\
50-100 \mu \mathrm{m}\end{array}$ & GFP (microglia) & Two-photon & $40 \times(N A=0.8)$ & $\begin{array}{l}1,024 \times 1,024 \text { pixel }(0.16 \\
\mu \mathrm{m} / \text { pixel) } \\
15 \text { planes with } 3 \mu \mathrm{m} \text { step }\end{array}$ & $\begin{array}{l}1 \min \\
-\end{array}$ & $\begin{array}{l}\text { Swiatkowski et al. } \\
\text { (75) }\end{array}$ \\
\hline $\begin{array}{l}\text { CX3CR1-GFP }+/- \\
\text { mice }\end{array}$ & $\begin{array}{l}\text { E12.5, } \\
14.5,17.5\end{array}$ & - & Coronal section & $\begin{array}{l}300 \mu \mathrm{m} \\
50 \mu \mathrm{m}\end{array}$ & GFP (microglia) & Confocal & $20 x(N A=0.5)$ & $\begin{array}{l}1,024 \times 1,024 \text { pixel } \\
72 \mu \mathrm{m} \text { with } 8 \mu \mathrm{m} \text { step }\end{array}$ & $\begin{array}{l}2 \mathrm{~min} \\
1 \mathrm{~h}\end{array}$ & Swinnen et al. (54) \\
\hline $\begin{array}{l}\text { CX3CR1-GFP }+/- \\
\text { mice }\end{array}$ & $8-10$ wo & Halothane & Cortex & $\begin{array}{l}300 \mu \mathrm{m} \\
-\end{array}$ & GFP (microglia) & Confocal & $40 \times(N A=0.8)$ & $\begin{array}{l}\text { - } \\
8-10 \text { planes with } 2 \mu \mathrm{m} \text { step }\end{array}$ & $\begin{array}{l}1 \min \\
-\end{array}$ & Wu et al. (76) \\
\hline $\begin{array}{l}\text { rd10;CX3CR1- } \\
\mathrm{GFP}^{+/-} \\
\text {mice }\end{array}$ & P21-24 & - & Eyecup & - & $\begin{array}{l}\text { GFP (microglia) } \\
\text { PI (dead cell) } \\
\text { Hoechst (nuclei) }\end{array}$ & Confocal & $40 x$ or $60 x$ & $\begin{array}{l}1,024 \times 1,024 \text { pixel } \\
-\end{array}$ & $\begin{array}{l}1 \mathrm{~min} \\
2 \mathrm{~h}\end{array}$ & Zhao et al. (77) \\
\hline
\end{tabular}

wo, week-old; mo, month-old; P, post-natal day; -, not available. 
via the bulbous tips, and in vivo live imaging showed similar results. Eyo et al. showed that microglial process induction was also enhanced when neural activity was enhanced by kainic acid (66). Furthermore, they found that inhibiting microglial process number increases and process attraction by P2Y12 KO worsened kainic acid-induced seizures. These results suggest that microglial-neuronal contact in the epileptic brain has a neuroprotective effect.

Pfeiffer et al. examined the effect of increased neural activity associated with long-term potentiation (LTP) induction on the dynamics of microglia. After LTP induction, the number of microglial process branches increased, but the speed of extension and retraction was unchanged (73). Furthermore, live imaging of microglia and dendritic spines revealed an increase in the duration of microglial contact with spines after LTP induction, resulting in a decrease in the number of contacts. Furthermore, these changes were abolished by treatment with NMDA receptor antagonists. Taken together, these findings and the report by Dissing-Olesen et al. (64) suggest that neuron-derived ATP released in an NMDA receptor-dependent manner may regulate microglial-synaptic interactions.

While many studies have focused on microglial responses to excitatory neuron-derived neurotransmitters, Fontainhas et al. also focused on the inhibitory neurotransmitter GABA (68). Bath application of bicuculline, an inhibitor of ionic GABAA receptors, increased the length, extension and retraction rate and number of microglial processes and branches. On the other hand, a bath application of GABA reduced all these parameters. These results indicated that GABA decreases the motility of microglia.

\section{Exploring the Regulatory Molecules of Microglial Dynamics Using Brain Injury Models}

Zhao et al. tested the involvement of microglia in rod photoreceptor cell death in retinal degeneration (77). Live imaging of retinal explants in the rd10 mouse model of retinal degeneration showed that microglia phagocytose propidium iodide (PI)-positive and PI-negative rod photoreceptor cells. Microglial morphology and the way of phagocytosing rod photoreceptor cell varied, with amoeboid microglia forming a phagocytic cup near the cell body, and microglia with processes forming a phagocytic cup at the tip of the process or using lamellipodia.

Avignone et al. used a mouse model of kainic acid-induced status epilepticus and performed live imaging of microglia in hippocampal acute slices (62). Forty-eight hours after status epilepticus, microglia showed morphological changes such as enlarged soma and shorter process, but there was no change in surveillance or the extension speed of microglial processes to the site of injury. However, there was an increase in the extent to which a single process was explored and an increase in the speed of process extension to $2 \mathrm{Me}-\mathrm{ADP}$. Eyo et al. also utilized a seizure model to examine the molecular mechanisms that regulate microglial contact with neurons and their relationship (67). Microglial process convergence (MPC), which is seen when microglia contact neurons, was used as an indicator of contact events. MPCs were increased when seizures were induced by kainic acid and pilocarpine. In addition, knocking out the CX3CR1 receptor, a fractalkine receptor, decreased MPCs, while treatment with its ligand CX3CL1 increased MPCs, indicating that the CX3CL1-CX3CR1 signaling pathway regulates microglial-neuron interactions. In addition, activation of CX3CR1 promoted IL-1 $\beta$ release from microglia. Furthermore, IL-1 $\beta$ promoted ATP release associated with increased neural activity and microglial process elongation via P2Y12 receptors. The aggravation of kainic acid- or pilocarpineinduced seizures in CX3CR1-KO mice suggests that microglia inhibit excessive neural activity by contacting neurons with elevated activity.

Carbonell et al. examined the response of mature microglia to thalamic damage (63). Acute slices were prepared 2, 3, 4, 6 , and 8 days after the stab lesion and the thalamus was observed. The mobility of microglia around the injured site was highest after 3 days, but the direction of migration was random. As intracellular signaling, the authors focused on cysteine-cysteine (CC) chemokines involved in homing to the site of injury by leukocytes. They also showed that inhibition of CCR5 reduced migration speed and distance of microglia.

Eyo et al. focused on perinatal stroke and examined the effects of stroke-related deficiencies of oxygen and glucose on microglial motility (65). To model stroke, they treated acute hippocampal slices with hypoxia or oxygen-glucose deprivation (OGD). Both treatments reduced microglial motility and caused microglial death. Next, they compared the dynamics of microglia after OGD in slices of P2-3 and P6-7 and found that the former showed a lower cell death rate, a longer latency to death, and higher motility of microglia. These results suggest that the sensitivity of microglia to OGD increases with development.

\section{Exploring the Molecules That Control the Morphology of Microglial Processes}

The acute slice experimental system, which allows for more detailed pharmacological and genetic interventions than in vivo systems, including gene transfer, may contribute to the elucidation of mechanisms and molecules that could not be discovered in vivo. Matyash et al. found that knocking out of CD39 and CD73, which mediate the degradation of extracellular ATP to adenosine, reduced the length of microglial processes as well as the branching number (71). In acute slices of CD39$\mathrm{KO}$ mice, the extension of microglial processes to ATP and the site of injury was suppressed. Microglial ramification was rescued by inhibition of the adenosine transporter and increased extracellular adenosine. A similar trend was observed in primary cultures of microglia. These results suggest that adenosine is important for the maintenance of the ramified morphology of microglia.

Madry et al. tested the possibility that the two-pore domain channel (THIK-1) regulates microglial process motility (52). THIK-1 is constitutively activated and is further activated upon activation of the $\mathrm{P} 2 \mathrm{Y} 12$ receptor. Inhibition of THIK-1 activation reduced the ramification and surveillance of microglia but did not affect the extension of processes to ATP. In contrast, inhibition of $\mathrm{P} 2 \mathrm{Y} 12$ receptors had no effect on the ramification or surveillance. Importantly, this research provided an interesting insight that directed extension and surveillance are distinct 
modes of microglial process dynamics and may be regulated by different molecular mechanisms.

Bernier et al. focused on the kinetics of filopodia growing from the main processes of microglia and observed that inhibition of actin polymerization by cytochalasin treatment stopped the extension and retraction of filopodia (9). Increasing intracellular cAMP concentrations by treatment with IBMX and norepinephrine reduced the number of large processes but increased the number of filopodia. Furthermore, activation of P2Y12 by ATP treatment abolished filopodia and promoted the elongation of large processes and the formation of bulbous tips. These results suggest that fluctuations in intracellular cAMP concentrations in the quiescent state lead to the formation of filopodia and random surveillance, whereas elevated extracellular ATP concentrations cause filopodia to retract, promoting unidirectional process extension and the formation of bulbous tips.

\section{Cultured Slice}

When using acute slices, the effects of factors released due to the damage associated with section preparation need to be recognized. Cultured slices may partly overcome this point by recovering during the incubation period. In contrast to acute slices which require the experiment to be completed within $4 \mathrm{~h}$ of brain sectioning to observe ramified microglia (52), a major advantage of using cultured slices is the ability to image a relatively long time after manipulation, as it allows us to elucidate microglial changes in response to temporal changes (e.g., neurite outgrowth and transformation of the injured area). In addition, it is also possible to develop systems that recapitulate the synaptic connections between pre- and post-neurons by coculturing distant but neural-connected brain regions (e.g., retinal ganglion cells in retina and dorsal LGN neurons). However, one must be cautious of the unique reorganization of nerve fibers and glial proliferation in cultured slices and the different characteristics of microglia in the superficial and lower layers of slices (86). Additionally, as is often the case in culture systems, minute differences in techniques between experimenters of culture specimens may lead to significant differences in the morphology of microglia that are sensitive to environmental changes. The membrane used for culture sections is also important.

Recently, Ogaki et al. focused on the fact that PTEE membranes, which are frequently used to place slices in culture, make live imaging using inverted microscopy difficult due to the low light transmission of PTFE membranes (10) (Table 3). The authors evaluated the performance of the collagen membrane by placing sections on the light-permeable collagen membrane instead of the PTFE membrane and culturing the slices. The results showed that there was no significant difference in the number and viability of neurons and microglia between slices cultured on the PTFE membrane and slices cultured on the collagen membrane. In addition, the microglial processes, filopodia as well as cell contours were more clearly observed on the collagen membrane during live imaging. These innovations will broaden the use of slice culture for live imaging of microglia.

\section{Studies on Microglial Dynamics That Require Long-Term Observation}

Ohsawa et al. examined the effect of ADP on microglial process extension; treatment with RGD, an integrin inhibitor, together with ADP bath application, inhibited process extension to ADP (82). In conjunction with other experiments, the authors indicated that activation of microglial P2Y12 by ATP, which increases the expression level of integrin $\beta 1$ and promotes adhesion to the extracellular matrix, is important for microglial process extension.

Although microglia are known to repopulate once removed, the function and motility of repopulated microglia have not been well-elucidated. Zhang et al. performed live imaging of retinal explant cultures to examine the response to ATP of repopulated microglia (87). After 60 days of repopulation, there was no change in basal process motility or the degree of process elongation during ATP treatment between repopulated and endogenous microglia.

In the cortical plate $(\mathrm{CP})$, microglia are temporarily absent from E15 to E16 and instead are abundant in the ventricular zone (VZ), subventricular zone (SVZ), and intermediate zone (IZ) (88). However, it is not clear why or how microglia are absent from the CP during this period: neurons arising in the VZ/SVZ migrate to the $\mathrm{CP}$ and divide into various subtypes corresponding to the cortical layer structure. Changes in the expression of transcription factors that control differentiation lead to abnormal layer structure and the emergence of ectopic neurons. Hattori et al. proposed and tested the hypothesis that microglia may be temporarily absent from the $\mathrm{CP}$ to prevent interference with the functional differentiation of $\mathrm{CP}$ neurons (79). Live imaging of slices prepared from E14 mice showed that microglia migrate from the $\mathrm{CP}$ to the meninges and that removal of the meninges reduced the amount of migration. A similar trend was observed using in vivo imaging in utero: contrary to the microglia in the $\mathrm{CP}$, microglia in the VZ/SVZ/IZ were observed to migrate in the apical direction. In addition, microglial migration was inhibited in slices prepared from CXCR4-KO mice, indicating that the CXCL12-CXCR4 signaling pathway may regulate microglial migration. At present, verification of cell migration along the dorsoventral axis can only be performed by live ex vivo imaging, and this study demonstrates the utility of slice culture imaging.

\section{Interactions Between Microglia and Other Cells}

Multinucleated neutrophils (PMNs), which invade the brain parenchyma during ischemia, injure neurons by eliciting inflammation. Neumann et al. tested the possibility that microglia may play a role in protecting neurons by removing neutrophils by phagocytosis (81). Oxygen glucose deprivation (OGD) treatment of cultured slices increased neuronal death, which was further accelerated by the addition of PMNs. On the other hand, the addition of microglia at the same time as PMN reduced some of the neuronal death. Next, to test the possibility of microglial phagocytosis of PMNs, the authors added fluorescently labeled PMNs and microglia to cultured slices and performed live imaging. Both endogenous and added microglia phagocytosed PMNs. It was also shown that the microglia phagocytosed both dead and live PMNs. Furthermore, treatment 
TABLE 3 | Experimental conditions of live imaging of microglia ex vivo (slice culture).

\begin{tabular}{|c|c|c|c|c|c|c|c|c|c|c|}
\hline Animal & Age & $\begin{array}{l}\text { Imaging } \\
\text { timing }\end{array}$ & Region & $\begin{array}{l}\text { Thickness } \\
\text { Depth from the } \\
\text { surface }\end{array}$ & Cellular visualization & Microscopy & Objective lens & $\begin{array}{l}\text { Resolution }(x, y) \\
\text { z stack }\end{array}$ & $\begin{array}{l}\text { Interval time } \\
\text { Total time }\end{array}$ & References \\
\hline $\begin{array}{l}\text { CX3CR1-GFP }+/- \\
\text { mice }\end{array}$ & P6-7 & 10-12 DIV & Hippocampus & $300 \mu \mathrm{m}$ & GFP (microglia) & Multi-photon & $25 x$ & $\begin{array}{l}- \\
21 \text { planes with } 1.5 \mu \mathrm{m} \text { step }\end{array}$ & $\begin{array}{l}1 \mathrm{~min} \\
15 \mathrm{~min}\end{array}$ & $\begin{array}{l}\text { Greenhalgh et al. } \\
\text { (78) }\end{array}$ \\
\hline $\begin{array}{l}\text { CX3CR1-GFP }+/- \\
\text { mice }\end{array}$ & E14 & - & Cortex & $350 \mu \mathrm{m}$ & GFP (microglia) & Confocal & - & - & $\begin{array}{l}30 \mathrm{~min} \\
8 \mathrm{~h}\end{array}$ & Hattori et al. (79) \\
\hline Iba1-EGFP ${ }^{+/-}$mice & P6-7 & 13-14 DIV & Hippocampus & $300 \mu \mathrm{m}$ & GFP (microglia) & Fluorescence & $20 \times(N A=0.45)$ & - & $\begin{array}{l}20 \mathrm{~min} \\
-\end{array}$ & $\begin{array}{l}\text { Katayama et al. } \\
\text { (80) }\end{array}$ \\
\hline Wistar rats & P7-9 & $10 \mathrm{DIV}$ & Hippocampus & $350 \mu \mathrm{m}$ & $\begin{array}{l}\text { CMTMR (microglia) } \\
\text { CMAC (PMN) }\end{array}$ & Confocal & - & - & - & $\begin{array}{l}\text { Neumann et al. } \\
\text { (81) }\end{array}$ \\
\hline $\begin{array}{l}\text { CX3CR1-GFP }+/- \\
\text { mice }\end{array}$ & P6 & 7-9 DIV & $\begin{array}{l}\text { Entorhinal- } \\
\text { hippocampus }\end{array}$ & $400 \mu \mathrm{m}$ & GFP (microglia) & Confocal & $30 x(N A=1.05)$ & $\begin{array}{l}- \\
21 \text { planes with } 1 \mu \mathrm{m} \text { step }\end{array}$ & $\begin{array}{l}30 s \\
-\end{array}$ & Ogaki et al. (10) \\
\hline Iba1-EGFP $+/-$ mice & P4-7 & - & Hippocampus & $400 \mu \mathrm{m}$ & GFP (microglia) & Confocal & $20 x$ & - 20 planes with $2 \mu \mathrm{m}$ step & $\begin{array}{l}5 \mathrm{~min} \\
1 \mathrm{~h}\end{array}$ & Ohsawa et al. (82) \\
\hline SD rats & P4-6 & 1-8 DIV & Hippocampus & $400 \mu \mathrm{m}$ & $\begin{array}{l}\text { IsolectinB4-FITC } \\
\text { (microglia) } \\
\text { Sytox Orange or } \\
\text { To-Pro-3 (dead cell) }\end{array}$ & Confocal & $20 \times(N A=0.7)$ & $\begin{array}{l}512 \times 512 \text { pixel } \\
5-10 \text { planes with } 5-8 \mu \mathrm{m} \\
\text { step }\end{array}$ & $\begin{array}{l}2-4 \min \\
2-11 \mathrm{~h}\end{array}$ & Petersen et al. (83) \\
\hline $\begin{array}{l}\text { Cx3cr1::CreER; } \\
\text { RC::LSL-tdTomato } \\
\text { mice }\end{array}$ & P4 & 10-19 DIV & Hippocampus & $\begin{array}{l}300 \mu \mathrm{m} \\
30 \mu \mathrm{m}\end{array}$ & $\begin{array}{l}\text { tdTomato (microglia) } \\
\text { neuron (iRFP) }\end{array}$ & Light sheet & $60 \times(N A=1)$ & $\begin{array}{l}0.13 \times 0.13 \mu \mathrm{m} \\
0.48 \mu \mathrm{m} \text { step }\end{array}$ & $\begin{array}{l}45-60 s \\
2-3 h\end{array}$ & $\begin{array}{l}\text { Weinhard et al. } \\
\text { (84) }\end{array}$ \\
\hline Rabbits & - & - & - & $350 \mu \mathrm{m}$ & $\begin{array}{l}\text { Tomato Lectin } 594 \\
\text { (microglia) }\end{array}$ & Confocal & $20 x$ & $\begin{array}{l}- \\
50-80 \mu \mathrm{m} \text { thick with } \\
2-5 \mu \mathrm{m} \text { step }\end{array}$ & $\begin{array}{l}15 \mathrm{~min} \\
5.5-6 \mathrm{~h}\end{array}$ & Zhang et al. (85) \\
\hline
\end{tabular}

E, embryonic day; P, post-natal day; DIV, day in vitro; -, not available. 
with RGD and GluNAc (an inhibitor of lectins) reduced PMN phagocytosis and accelerated OGD treatment-induced neuronal death. These results suggest that phagocytosis of PMNs by microglia is neuroprotective.

Using live imaging of hippocampal culture slices, Weinhard et al. were able to capture the series of process in which microglia phagocytose the presynaptic structures (boutons) formed by dentate gyrus granule cells (84). They did not identify any instances of microglia phagocytosis of dendritic spines and argued that, at least under physiological conditions, microglia may preferentially phagocytose presynaptic components.

\section{Studies on Brain Injury and Brain Diseases}

In Petersen et al., the response of microglia to damaged neurons was observed at 1 7 DIV (83). When adjacent cells died, microglia extended their own processes and phagocytosed the dead cells. The motility of microglial processes changed after contact with other microglia and dead cells, suggesting that contact determines the target for phagocytosis.

Katayama et al. subjected neurons to excitotoxicity by NMDA and observed the response of microglia to injured neurons (80). Microglia accumulated in the pyramidal cell layer after injury, indicating that this was independent of microglial proliferation. In addition, PI-positive neurons disappeared after being surrounded by microglia, and this was inhibited by removal of the microglia by clodronate treatment, suggesting that microglia phagocytose the injured neurons. Furthermore, the authors showed that phagocytosis of PI-positive neurons was promoted by $\mathrm{p} 38$ MAP kinase.

Anti-inflammatory therapy that targets microglia to block the microglial inflammatory response in cerebral palsy and autism is currently being explored. Zhang et al. used E. coliinduced maternal immune activations (MIAs) in rabbit fetuses and prepared hemispheric slice cultures to examine microglial migration and the interaction between microglia and dendrimers (85). Microglia in the MIA group exhibited an amoeboid shape, and their migration speed and distance were reduced. Since the microglia in the MIA group took up more dendrimers at a faster time, the authors claimed that the change in microglial motility was due to an interaction with dendrimers and proposed that assays using culture slices could be useful for drug discovery.

Greenhalgh et al. examined the effect of bone marrowderived macrophages on the responsiveness of microglia during tissue injury (78). Cultured slices were laser-irradiated, and the induction of microglial processes to the irradiated area was quantified. There was no change in each parameter of process extension in the presence or absence of macrophages.

\section{IN VITRO (DISPERSED CELL CULTURE)}

In section Ex vivo Live Imaging, live imaging of microglia using acute or cultured slices was introduced. Slice imaging has clearly broadened the scope of microglial studies, as it allows live imaging of the brain in its layered structure without area limitations. However, the heterogeneity of microglia depends on the position of the slice, which must be noted in slice imaging (86). Thus, most papers specify in the materials and methods section how much depth (Z-axis distance) the imaging was performed from the surface of the slice. It is important to have some degree of homogeneity in microglial conditions before treatment, especially when comparing microglial morphology and function between the control and treated groups. To overcome the heterogeneity of microglia, dispersed cultures would be useful. The greatest advantage of using dispersed cultures is that the cell types present in the observation system can be regulated according to the purpose of the experiment, which is naturally different from the in vivo conditions though. These features make it possible to clarify which cell type a particular phenomenon strongly depends on, and may facilitate the screening of the molecular mechanisms involved. Taking advantage of this, cell culture systems have been widely used for disease research, pharmacological screening, and, more recently, iPS microglia research. In the future, more sophisticated cell culture systems, especially in terms of reproducing in vivo microglial morphology, will be needed to validate cell-cell interactions that underlie neural circuitry and brain function.

The medium and presence of heterogeneous cells may have a significant impact on the morphology and functions of microglia. For example, Montilla et al. examined the effect of medium composition on microglial properties (93). Compared to DMEM $+10 \%$ FBS, the use of TIC medium which contains TGF$\beta$, IL-34, and cholesterol (8) resulted in an increase in microglial process number, changes in purine receptor expression levels, reduced phagocytic ability, and increased motility (movement speed and distance traveled), which indicated that serum significantly influences microglial conditions. There is also a significant influence of serum; Rizzi et al. examined the effect of NGF on the behavior of microglia (94), finding that microglial motility, which was defined as the degree of change in the ratio of cell area/cell perimeter length, was increased by NGF, although the cell body migration speed did not change.

\section{Disease Research}

As mentioned above, the contribution of cell culture to disease research and drug screening systems is significant. Therefore, we present here a chronological list of some of the most important disease studies using live imaging of cell cultures. To mimic Huntington disease, microglia were cocultured with striatal and cortical neurons expressing Htt mutants (91) (Table 4). Live imaging showed that microglia moved into the vicinity of neuronal projections, which were then torn off. These results suggest that microglia cause neuronal degeneration.

To establish an in vitro model of amyotrophic lateral sclerosis (ALS), Frakes et al. cultured motor neurons from wild-type mice with microglia isolated by density gradient centrifugation from adult wild-type or SOD1-G93 mice (ALS model) (89). Seventytwo hours after the start of coculture, the number of motor neurons cocultured with microglia from the ALS model mice was reduced to $\sim 50 \%$ of the number when cocultured with microglia from wild-type mice. When shRNA against the SOD1 mutant was expressed by lentiviruses to reduce SOD1 expression in microglia to $\sim 25 \%$, the reduction in motor neuron numbers was rescued. The authors also showed that the SOD1 mutant 


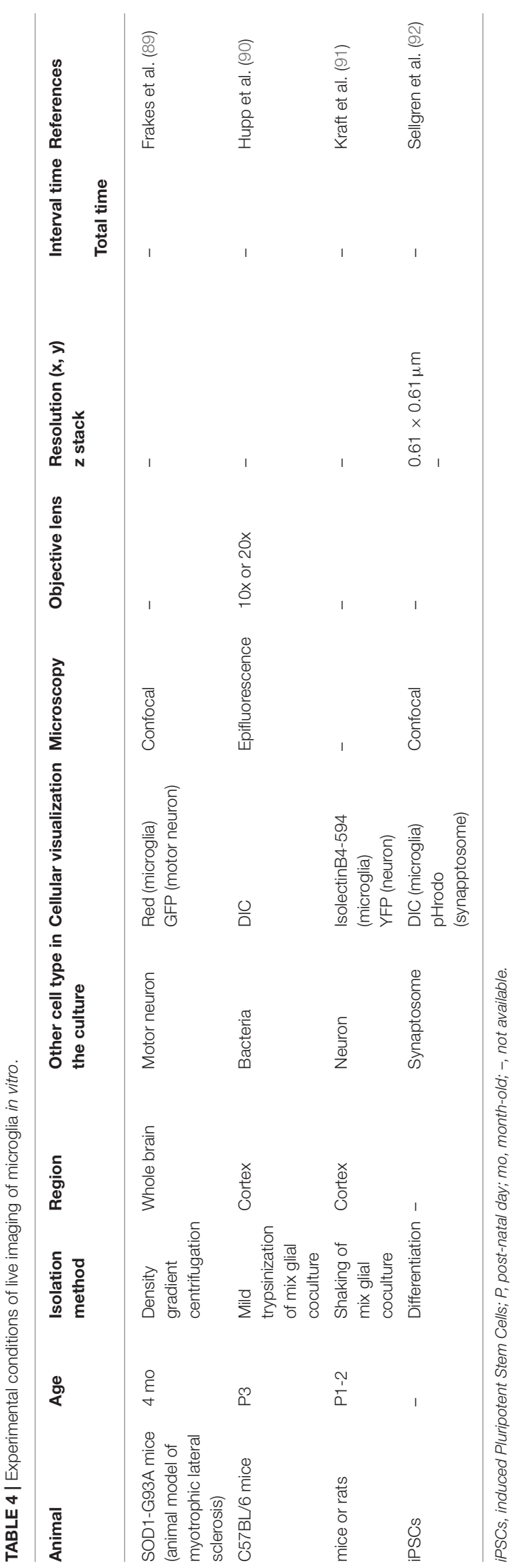

caused microglial inflammatory responses (increased expression of CD68, iNOS, and ROS) and motor neuron death via activation of NFкB. It should be noted that coculture with microglia did not affect neuronal death when microglia were isolated from neonatal microglia, suggesting that even isolated microglia may be able to reflect the condition of the derived individual to some extent.

In Hupp et al., the effect of Streptococcus pneumoniae on the function of microglia was examined (90). In both isolated cultures of microglia and cocultures with astrocytes, exposure to Streptococcus pneumoniae resulted in reduced chemotaxis to the bacteria and motility of microglia. This could be a strategy by which Streptococcus pneumoniae escapes phagocytosis by microglia.

Sellgren et al. developed an in vitro model of microgliadependent synaptic removal to test the possibility that excessive synaptic removal may contribute to schizophrenia (92). The authors showed that synaptosomes derived from schizophrenia patients were more likely to be phagocytosed and that patientderived microglia-like cells (iMGs) had a higher phagocytosis capacity. Furthermore, they found that C4, a schizophrenia risk gene, was involved in complement tagging to neurons and synaptic removal by microglia. Additionally, minocycline inhibited synaptic removal and reduced the risk of developing schizophrenia. Although representative images of differentiated iMGs showed a morphology relatively close to that in vivo, no image was presented to show the morphology of iMGs during synaptosome phagocytosis.

As reported by Hupp and Sellgren (see above), another advantage of the cell culture system is that the process of phagocytosis is easier to observe than other experimental systems. Taking advantage of this, Zhao et al. examined the effect of activation of mTOR signaling on phagocytosis in microglia (72). They added pHrodo to primary cultures of microglia and measured its uptake, finding that phagocytosis was enhanced in TSC1Cx3cr1CKO mice compared with microglia derived from wild-type mice. It should be noted that there are still no studies which succeeded in reproducing ramified morphology of microglia in the co-culture of microglia and neurons, and that in vitro system probably failed to reflect how microglia phagocyte neurons and synapses in vivo.

\section{Sophistication of Culture Systems}

One of the most challenging aspects of microglial isolation and culture is recreating microglial morphology in vivo, and there have been many attempts to improve the morphology of microglia in culture. For example, it has been shown that ATP, which promotes microglial process extension, increases the number of microglial primary processes (95). Thus, it would be useful to target molecules that have already been shown to regulate microglial ramification in vivo and ex vivo.

It has also been shown that the method of coating the surface of the culture dish may affect microglial morphology $(96,97)$. A strong candidate for factors that promote microglial ramification are astrocyte-derived molecules; since the 1990s, coculturing microglia with astrocytes and adding astrocyte culture supernatants (ACMs) to isolated cultures of microglial 
conditions have been used to improve microglia in vitro (6, $98,99)$. Recently, among astrocyte-derived factors, CSF-1, TGF$\beta$, and cholesterol were found to be required for microglial ramification (8). This work was a breakthrough in microglial culture, as it allowed for studies to use in vivo-like microglia without coculturing with other cell types.

Because microglial functions, such as exploration of the brain environment and phagocytosis, are strongly dependent on the morphology of the process, recreating the ramified process is particularly important. Hyperramified microglia have been reported in the diseased brains of chronic despair models and alcoholism models $(100,101)$. Using electron microscopy, Bisht et al. also reported the existence of microglia with highly ramified processes, called dark microglia, in pathological conditions such as stress and Alzheimer's disease (102). A group of microglial genes whose expression levels are altered in each animal model is also being elucidated by RNA sequencing. Using this information, methods to promote microglial ramification in vitro may be discovered.

However, it should be noted that the ramified morphology of microglia in vitro does not necessarily reflect the characteristics of transcriptome under physiological conditions in vivo. Indeed, Bohlen et al. mentioned this limitation by comparing the RNA-sequence data between cultured microglia with ramified morphology and freshly isolated microglia (8).

\section{CONCLUSION AND PERSPECTIVE}

In section Achievement and Limitation of in vivo Live Imaging, we described studies that have performed live imaging of microglia in vivo, ex vivo (acute slice and cultured slice), and in vitro (primary culture). Although we have not been able to cover all of the published papers, the number of papers is roughly in the order of in vivo, ex vivo, and in vitro. In vitro systems are easier than other experimental systems to perform pharmacological and genetic manipulations (e.g., induction of synaptic competition, which is important in neuronmicroglial interactions). In addition, multicolor live imaging is essential to investigate the relationship between microglia and synapses. Since a synaptic site contains at least four components, i.e., microglia, astrocytes, pre-synapses, and post-synapses, all of these components should be imaged as simultaneously as possible at high resolution to assess the function and identity of "quadripartite synapses" (103-105). The pros of in vitro system is that multicolor live imaging can be accomplished without the need of complicated breeding schemes and crossings of transgenic animals to label multiple cellular elements.

However, live imaging systems using in vitro tools still have limitations that need to be solved. The most critical point is that in vitro microglia differ from in vivo and ex vivo microglia in that they exhibit an abnormal form (hypertrophy of the cell body and loss of fine processes). This microglial morphological abnormality is unsuitable for examining microglial-synaptic interactions, which have recently received considerable attention among microglial functions. Conversely, if we can establish an in vitro experimental system that overcomes the abnormal morphology, it would be a breakthrough that could greatly advance microglial research. In particular, in the case of microglial-synaptic interactions, the detailed molecular mechanisms cannot be explored without observing and manipulating cell-cell interactions in the glianeural circuit complex. For example, other than microglia, the involvement of astrocytes cannot be disregarded. Astrocyte micro-processes surround pre-synapses and post-synapses, forming a tripartite synapse structure (106). The formation of tripartite synapses is then promoted by increased neural activity (107). Therefore, to elucidate the activity-dependent microglial-synaptic interaction, a four-party structure that adds microglia to the conventional tripartite synapse, or quadripartite synapse, should be studied. To do so, it is necessary to solve the difficult problem of morphological abnormalities in cultured microglia. If we can induce synaptic competition at the individual synapse level and subsequently detect changes in glial intracellular signaling and glial gene expression, we will obtain many novel insights into the synaptic plasticity that underlies brain function (Figure 2). In addition to morphological abnormalities, discrepancies of gene expression characteristics with in vivo microglia are also issues to be solved in in vitro experimental systems. In the future, it is expected to develop in vitro experimental systems that mimic the gene expression characteristics of microglia in vivo.

Another significant limitation of using in vitro systems may be the inability to fully reproduce the brain environment. There are many components of the brain that are lacking in cell culture and may affect microglial morphology and function, such as the blood brain barrier (BBB), blood vessels, extracellular matrix (ECM), and other cell types. In recent years, many attempts have been made to reconstitute BBB, blood vessels, and ECM in vitro $(108,109)$ and to culture ramified microglia with other cell types (110).

In conclusion, in order to understand the role of microglial dynamics in brain function and the underlying cellular and molecular mechanisms, it is important to develop appropriate in vitro live imaging systems that reflect the findings of in vivo live imaging and fully exploit the convenience of genetic and pharmacological manipulation of brain cells in vitro.

\section{AUTHOR CONTRIBUTIONS}

MA and RK wrote the manuscript. Both authors contributed to the article and approved the submitted version.

\section{FUNDING}

This research was funded by [JSPS] grant number [20H05897] and by [JST] grant number [JPMJPR18H4]. 


\section{REFERENCES}

1. Nimmerjahn A, Kirchhoff F, Helmchen F. Resting microglial cells are highly dynamic surveillants of brain parenchyma in vivo. Science. (2005) 308:13148. doi: 10.1126/science.1110647

2. Davalos D, Grutzendler J, Yang G, Kim JV, Zuo Y, Jung S, et al. ATP mediates rapid microglial response to local brain injury in vivo. Nat Neurosci. (2005) 8:752-8. doi: $10.1038 / \mathrm{nn} 1472$

3. Wake H, Moorhouse AJ, Jinno S, Kohsaka S, Nabekura J. Resting microglia directly monitor the functional state of synapses in vivo and determine the fate of ischemic terminals. J Neurosci. (2009) 29:397480. doi: 10.1523/JNEUROSCI.4363-08.2009

4. Colonna M, Butovsky O. Microglia function in the central nervous system during health and neurodegeneration. Annu Rev Immunol. (2017) 35:44168. doi: 10.1146/annurev-immunol-051116-052358

5. Xu HT, Pan F, Yang G, Gan WB. Choice of cranial window type for in vivo imaging affects dendritic spine turnover in the cortex. Nat Neurosci. (2007) 10:549-51. doi: 10.1038/nn1883

6. Stence N, Waite M, Dailey ME. Dynamics of microglial activation: a confocal time-lapse analysis in hippocampal slices. Glia. (2001) 33:256-66. doi: 10.1002/1098-1136(200103)33:3<256::AID-GLIA1024>3.0.CO;2-J

7. Tanaka J, Maeda N. Microglial ramification requires nondiffusible factors derived from astrocytes. Exp Neurol. (1996) 137:36775. doi: 10.1006/exnr.1996.0038

8. Bohlen CJ, Bennett FC, Tucker AF, Collins HY, Mulinyawe SB, Barres BA. Diverse requirements for microglial survival, specification, and function revealed by defined-medium cultures. Neuron. (2017) 94:75973.e8. doi: 10.1016/j.neuron.2017.04.043

9. Bernier LP, Bohlen CJ, York EM, Choi HB, Kamyabi A, Dissing-Olesen L, et al. Nanoscale surveillance of the brain by microglia via cAMP-Regulated filopodia. Cell Rep. (2019) 27:2895-908.e4. doi: 10.1016/j.celrep.2019.05.010

10. Ogaki A, Araki T, Ishikawa M, Ikegaya Y, Koyama R. A live imaging-friendly slice culture method using collagen membranes. Neuropsychopharmacol Rep. (2020) 40:307-13. doi: 10.1002/npr2.12128

11. Abiega O, Beccari S, Diaz-Aparicio I, Nadjar A, Layé S, Leyrolle Q, et al. Neuronal hyperactivity disturbs ATP microgradients, impairs microglial motility, and reduces phagocytic receptor expression triggering apoptosis/microglial phagocytosis uncoupling. PLoS Biol. (2016) 14:e1002466. doi: 10.1371/journal.pbio.1002466

12. Askew K, Li K, Olmos-Alonso A, Garcia-Moreno F, Liang Y, Richardson $\mathrm{P}$, et al. Coupled proliferation and apoptosis maintain the rapid turnover of microglia in the adult brain. Cell Rep. (2017) 18:391405. doi: 10.1016/j.celrep.2016.12.041

13. Badimon A, Strasburger HJ, Ayata P, Chen X, Nair A, Ikegami A, et al. Negative feedback control of neuronal activity by microglia. Nature. (2020) 586:417-23. doi: 10.1038/s41586-020-2777-8

14. Brawek B, Liang Y, Savitska D, Li K, Fomin-Thunemann N, Kovalchuk Y, et al. A new approach for ratiometric in vivo calcium imaging of microglia. Sci Rep. (2017) 7:6030. doi: 10.1038/s41598-017-05952-3

15. Casano AM, Albert M, Peri F. Developmental apoptosis mediates entry and positioning of microglia in the zebrafish brain. Cell Rep. (2016) 16:897906. doi: 10.1016/j.celrep.2016.06.033

16. Cruz-Martin A, Portera-Cailliau C. In vivo imaging of axonal and dendritic structures in neonatal mouse cortex. Cold Spring Harb Protoc. (2014) 2014:57-64. doi: 10.1101/pdb.prot080150

17. Damisah EC, Hill RA, Rai A, Chen F, Rothlin CV, Ghosh S, et al Astrocytes and microglia play orchestrated roles and respect phagocytic territories during neuronal corpse removal in vivo. Sci Adv. (2020) 6:eaba3239. doi: 10.1126/sciadv.aba3239

18. Davalos D, Akassoglou K. In vivo imaging of the mouse spinal cord using two-photon microscopy. J Vis Exp. (2012) e2760. doi: 10.3791/2760

19. Davalos D, Ryu JK, Merlini M, Baeten KM, Le Moan N, Petersen MA, et al. Fibrinogen-induced perivascular microglial clustering is required for the development of axonal damage in neuroinflammation. Nat Commun. (2012) 3:1227. doi: $10.1038 /$ ncomms 2230

20. Dibaj P, Nadrigny F, Steffens H, Scheller A, Hirrlinger J, Schomburg ED, et al. NO mediates microglial response to acute spinal cord injury under ATP control in vivo. Glia. (2010) 58:1133-44. doi: 10.1002/glia.20993
21. Eichhoff G, Brawek B, Garaschuk O. Microglial calcium signal acts as a rapid sensor of single neuron damage in vivo. Biochim Biophys Acta. (2011) 1813:1014-24. doi: 10.1016/j.bbamcr.2010.10.018

22. Füger P, Hefendehl JK, Veeraraghavalu K, Wendeln AC, Schlosser C, Obermüller U, et al. Microglia turnover with aging and in an Alzheimer's model via long-term in vivo single-cell imaging. Nat Neurosci. (2017) 20:1371-6. doi: 10.1038/nn.4631

23. Grier BD, Belluscio L, Cheetham CE. Olfactory sensory activity modulates microglial-neuronal interactions during dopaminergic cell loss in the olfactory bulb. Front Cell Neurosci. (2016) 10:178. doi: 10.3389/fncel.2016.00178

24. Grutzendler J, Yang G, Pan F, Parkhurst CN, Gan WB. Transcranial twophoton imaging of the living mouse brain. Cold Spring Harb Protoc. (2011) 2011:1080-8. doi: 10.1101/pdb.prot065474

25. Gu L, Kleiber S, Schmid L, Nebeling F, Chamoun M, Steffen $\mathrm{J}$, et al. Long-term in vivo imaging of dendritic spines in the hippocampus reveals structural plasticity. J Neurosci. (2014) 34:13948-53. doi: 10.1523/JNEUROSCI.1464-14.2014

26. Haynes SE, Hollopeter G, Yang G, Kurpius D, Dailey ME, Gan WB, et al. The P2Y12 receptor regulates microglial activation by extracellular nucleotides. Nat Neurosci. (2006) 9:1512-9. doi: 10.1038/nn1805

27. Herzog C, Pons Garcia L, Keatinge M, Greenald D, Moritz C, Peri F, et al. Rapid clearance of cellular debris by microglia limits secondary neuronal cell death after brain injury. Development. (2019) 146:dev174698. doi: 10.1242/dev.174698

28. Hill RA, Li AM, Grutzendler J. Lifelong cortical myelin plasticity and agerelated degeneration in the live mammalian brain. Nat Neurosci. (2018) 21:683-95. doi: 10.1038/s41593-018-0120-6

29. Hristovska I, Verdonk F, Comte JC, Tsai ES, Desestret V, Honnorat $\mathrm{J}$, et al. Ketamine/xylazine and barbiturates modulate microglial morphology and motility differently in a mouse model. PLoS ONE. (2020) 15:e0236594. doi: 10.1371/journal.pone.0236594

30. Hutter G, Theruvath J, Graef CM, Zhang M, Schoen MK, Manz EM, et al. Microglia are effector cells of CD47-SIRP $\alpha$ antiphagocytic axis disruption against glioblastoma. Proc Natl Acad Sci USA. (2019) 116:9971006. doi: 10.1073/pnas.1721434116

31. Isshiki $\mathrm{M}$, Okabe S. Evaluation of cranial window types for in vivo two-photon imaging of brain microstructures. Microscopy. (2014) 63:5363. doi: 10.1093/jmicro/dft043

32. Li Y, Du XF, Liu CS, Wen ZL, Du JL. Reciprocal regulation between resting microglial dynamics and neuronal activity in vivo. Dev Cell. (2012) 23:1189202. doi: 10.1016/j.devcel.2012.10.027

33. Liu YU, Ying Y, Li Y, Eyo UB, Chen T, Zheng J, et al. Neuronal network activity controls microglial process surveillance in awake mice via norepinephrine signaling. Nat Neurosci. (2019) 22:1771-81. doi: 10.1038/s41593-019-0511-3

34. Miyamoto A, Wake H, Ishikawa AW, Eto K, Shibata K, Murakoshi H, et al. Microglia contact induces synapse formation in developing somatosensory cortex. Nat Commun. (2016) 7:12540. doi: 10.1038/ncomms12540

35. Morsch M, Radford R, Lee A, Don EK, Badrock AP, Hall TE, et al. In vivo characterization of microglial engulfment of dying neurons in the zebrafish spinal cord. Front Cell Neurosci. (2015) 9:321. doi: 10.3389/fncel.2015.00321

36. Olmedillas Del Moral M, Asavapanumas N, Uzcátegui NL, Garaschuk O. Healthy brain aging modifies microglial calcium signaling in vivo. Int J Mol Sci. (2019) 20:589. doi: 10.3390/ijms20030589

37. Parkhurst CN, Yang G, Ninan I, Savas JN, Yates JR, Lafaille JJ, et al. Microglia promote learning-dependent synapse formation through brain-derived neurotrophic factor. Cell. (2013) 155:1596609. doi: 10.1016/j.cell.2013.11.030

38. Peri F, Nüsslein-Volhard C. Live imaging of neuronal degradation by microglia reveals a role for v0-ATPase al in phagosomal fusion in vivo. Cell. (2008) 133:916-27. doi: 10.1016/j.cell.2008.04.037

39. Pozner A, Xu B, Palumbos S, Gee JM, Tvrdik P, Capecchi MR Intracellular calcium dynamics in cortical microglia responding to focal laser injury in the PC::G5-tdT reporter mouse. Front Mol Neurosci. (2015) 8:12. doi: $10.3389 /$ fnmol.2015.00012

40. Pryazhnikov E, Mugantseva E, Casarotto P, Kolikova J, Fred SM, Toptunov D, et al. Longitudinal two-photon imaging in somatosensory 
cortex of behaving mice reveals dendritic spine formation enhancement by subchronic administration of low-dose ketamine. Sci Rep. (2018) 8:6464. doi: 10.1038/s41598-018-24933-8

41. Stowell RD, Sipe GO, Dawes RP, Batchelor HN, Lordy KA, Whitelaw BS, et al. Noradrenergic signaling in the wakeful state inhibits microglial surveillance and synaptic plasticity in the mouse visual cortex. Nat Neurosci. (2019) 22:1782-92. doi: 10.1038/s41593-019-0514-0

42. Sun W, Suzuki K, Toptunov D, Stoyanov S, Yuzaki M, Khiroug L, et al. Twophoton imaging of anesthesia-specific alterations in microglial surveillance and photodamage-directed motility in mouse cortex. Front Neurosci. (2019) 13:421. doi: 10.3389/fnins.2019.00421

43. Taylor S, Mehina E, White E, Reeson P, Yongblah K, Doyle KP, et al. Suppressing interferon- $\gamma$ stimulates microglial responses and repair of microbleeds in the diabetic brain. J Neurosci. (2018) 38:870722. doi: 10.1523/JNEUROSCI.0734-18.2018

44. Tremblay M, Lowery RL, Majewska AK. Microglial interactions with synapses are modulated by visual experience. PLoS Biol. (2010) 8:e1000527. doi: 10.1371/journal.pbio.1000527

45. Umpierre AD, Bystrom LL, Ying Y, Liu YU, Worrell G, Wu LJ. Microglial calcium signaling is attuned to neuronal activity in awake mice. Elife. (2020) 9:e56502. doi: 10.7554/eLife.56502

46. Yang G, Pan F, Parkhurst CN, Grutzendler J, Gan WB. Thinned-skull cranial window technique for long-term imaging of the cortex in live mice. Nat Protoc. (2010) 5:201-8. doi: 10.1038/nprot.2009.222

47. Yu X, Zuo Y. Two-photon in vivo imaging of dendritic spines in the mouse cortex using a thinned-skull preparation. J Vis Exp. (2014) 87:51520. doi: $10.3791 / 51520$

48. Dorand RD, Barkauskas DS, Evans TA, Petrosiute A, Huang AY. Comparison of intravital thinned skull and cranial window approaches to study CNS immunobiology in the mouse cortex. Intravital. (2014) 3:e29728. doi: 10.4161/intv.29728

49. Shih AY, Driscoll JD, Drew PJ, Nishimura N, Schaffer CB, Kleinfeld D. Two-photon microscopy as a tool to study blood flow and neurovascular coupling in the rodent brain. J Cereb Blood Flow Metab. (2012) 32:1277309. doi: $10.1038 / \mathrm{jcbfm} .2011 .196$

50. Huh Y, Cho J. Urethane anesthesia depresses activities of thalamocortical neurons and alters its response to nociception in terms of dual firing modes. Front Behav Neurosci. (2013) 7:141. doi: 10.3389/fnbeh.2013.00141

51. Li N, Lee B, Liu RJ, Banasr M, Dwyer JM, Iwata M, et al. mTOR-dependent synapse formation underlies the rapid antidepressant effects of NMDA antagonists. Science. (2010) 329:959-64. doi: 10.1126/science.1190287

52. Madry C, Kyrargyri V, Arancibia-Cárcamo IL, Jolivet R, Kohsaka S, Bryan RM, et al. Microglial ramification, surveillance, and interleukin-1 $\beta$ release are regulated by the two-pore domain K. Neuron. (2018) 97:299312.e6. doi: 10.1016/j.neuron.2017.12.002

53. Xu J, Wang $\mathrm{T}$, Wu $\mathrm{Y}$, Jin $\mathrm{W}$, Wen Z. Microglia colonization of developing zebrafish midbrain is promoted by apoptotic neuron and lysophosphatidylcholine. Dev Cell. (2016) 38:21422. doi: 10.1016/j.devcel.2016.06.018

54. Swinnen N, Smolders S, Avila A, Notelaers K, Paesen R, Ameloot M, et al. Complex invasion pattern of the cerebral cortex by microglial cells during development of the mouse embryo. Glia. (2013) 61:15063. doi: $10.1002 /$ glia.22421

55. Ginhoux F, Greter M, Leboeuf M, Nandi S, See P, Gokhan S, et al. Fate mapping analysis reveals that adult microglia derive from primitive macrophages. Science. (2010) 330:841-5. doi: 10.1126/science. 1194637

56. Eyo UB, Miner SA, Weiner JA, Dailey ME. Developmental changes in microglial mobilization are independent of apoptosis in the neonatal mouse hippocampus. Brain Behav Immun. (2016) 55:49-59. doi: 10.1016/j.bbi.2015.11.009

57. Paolicelli RC, Bolasco G, Pagani F, Maggi L, Scianni M, Panzanelli P, et al. Synaptic pruning by microglia is necessary for normal brain development. Science. (2011) 333:1456-8. doi: 10.1126/science.1202529

58. Schafer DP, Lehrman EK, Kautzman AG, Koyama R, Mardinly AR, Yamasaki R, et al. Microglia sculpt postnatal neural circuits in an activity and complement-dependent manner. Neuron. (2012) 74:691705. doi: 10.1016/j.neuron.2012.03.026
59. Baker H, Morel K, Stone DM, Maruniak JA. Adult naris closure profoundly reduces tyrosine hydroxylase expression in mouse olfactory bulb. Brain Res. (1993) 614:109-16. doi: 10.1016/0006-8993(93)91023-1

60. Sawada M, Kaneko N, Inada H, Wake H, Kato Y, Yanagawa Y, et al. Sensory input regulates spatial and subtype-specific patterns of neuronal turnover in the adult olfactory bulb. J Neurosci. (2011) 31:1158796. doi: 10.1523/JNEUROSCI.0614-11.2011

61. Gholamin S, Mitra SS, Feroze AH, Liu J, Kahn SA, Zhang M, et al. Disrupting the CD47-SIRP $\alpha$ anti-phagocytic axis by a humanized anti-CD47 antibody is an efficacious treatment for malignant pediatric brain tumors. Sci Transl Med. (2017) 9:eaaf2968. doi: 10.1126/scitranslmed.aaf2968

62. Avignone E, Lepleux M, Angibaud J, Nägerl UV. Altered morphological dynamics of activated microglia after induction of status epilepticus. $J$ Neuroinflammation. (2015) 12:202. doi: 10.1186/s12974-015-0421-6

63. Carbonell WS, Murase S, Horwitz AF, Mandell JW. Migration of perilesional microglia after focal brain injury and modulation by CC chemokine receptor 5: an in situ time-lapse confocal imaging study. J Neurosci. (2005) 25:70407. doi: 10.1523/JNEUROSCI.5171-04.2005

64. Dissing-Olesen L, LeDue JM, Rungta RL, Hefendehl JK, Choi HB, MacVicar BA. Activation of neuronal NMDA receptors triggers transient ATPmediated microglial process outgrowth. J Neurosci. (2014) 34:1051127. doi: 10.1523/JNEUROSCI.0405-14.2014

65. Eyo U, Dailey ME. Effects of oxygen-glucose deprivation on microglial mobility and viability in developing mouse hippocampal tissues. Glia. (2012) 60:1747-60. doi: 10.1002/glia.22394

66. Eyo UB, Peng J, Swiatkowski P, Mukherjee A, Bispo A, Wu LJ. Neuronal hyperactivity recruits microglial processes via neuronal NMDA receptors and microglial P2Y12 receptors after status epilepticus. J Neurosci. (2014) 34:10528-40. doi: 10.1523/JNEUROSCI.0416-14.2014

67. Eyo UB, Peng J, Murugan M, Mo M, Lalani A, Xie $P$, et al. Regulation of physical microglia-neuron interactions by fractalkine signaling after status epilepticus. eNeuro. (2016) 3:ENEURO.020916.2016. doi: 10.1523/ENEURO.0209-16.2016

68. Fontainhas AM, Wang M, Liang KJ, Chen S, Mettu P, Damani M, et al. Microglial morphology and dynamic behavior is regulated by ionotropic glutamatergic and GABAergic neurotransmission. PLOS ONE. (2011) 6:e15973. doi: 10.1371/journal.pone.0015973

69. Gyoneva S, Traynelis SF. Norepinephrine modulates the motility of resting and activated microglia via different adrenergic receptors. J Biol Chem. (2013) 288:15291-302. doi: 10.1074/jbc.M113.458901

70. Gyoneva S, Davalos D, Biswas D, Swanger SA, Garnier-Amblard E, Loth F, et al. Systemic inflammation regulates microglial responses to tissue damage in vivo. Glia. (2014) 62:1345-60. doi: 10.1002/glia.22686

71. Matyash M, Zabiegalov O, Wendt S, Matyash V, Kettenmann H. The adenosine generating enzymes CD39/CD73 control microglial processes ramification in the mouse brain. PLoS ONE. (2017) 12:e0175012. doi: 10.1371/journal.pone.0175012

72. Zhao X, Liao Y, Morgan S, Mathur R, Feustel P, Mazurkiewicz J, et al. Noninflammatory changes of microglia are sufficient to cause epilepsy. Cell Rep. (2018) 22:2080-93. doi: 10.1016/j.celrep.2018.02.004

73. Pfeiffer T, Avignone E, Nägerl UV. Induction of hippocampal longterm potentiation increases the morphological dynamics of microglial processes and prolongs their contacts with dendritic spines. Sci Rep. (2016) 6:32422. doi: $10.1038 /$ srep 32422

74. Rotterman TM, Alvarez FJ. Microglia dynamics and interactions with motoneurons axotomized after nerve injuries revealed by two-photon imaging. Sci Rep. (2020) 10:8648. doi: 10.1038/s41598-020-65363-9

75. Swiatkowski P, Murugan M, Eyo UB, Wang Y, Rangaraju S, Oh SB, et al. Activation of microglial P2Y12 receptor is required for outward potassium currents in response to neuronal injury. Neuroscience. (2016) 318:2233. doi: $10.1016 /$ j.neuroscience.2016.01.008

76. Wu LJ, Vadakkan KI, Zhuo M. ATP-induced chemotaxis of microglial processes requires $\mathrm{P} 2 \mathrm{Y}$ receptor-activated initiation of outward potassium currents. Glia. (2007) 55:810-21. doi: 10.1002/glia.20500

77. Zhao L, Zabel MK, Wang X, Ma W, Shah P, Fariss RN, et al. Microglial phagocytosis of living photoreceptors contributes to inherited retinal degeneration. EMBO Mol Med. (2015) 7:1179-97. doi: 10.15252/emmm.201505298 
78. Greenhalgh AD, Zarruk JG, Healy LM, Baskar Jesudasan SJ, Jhelum P, Salmon CK, et al. Peripherally derived macrophages modulate microglial function to reduce inflammation after CNS injury. PLoS Biol. (2018) 16:e2005264. doi: 10.1371/journal.pbio.200 5264

79. Hattori Y, Naito Y, Tsugawa Y, Nonaka S, Wake H, Nagasawa $\mathrm{T}$, et al. Transient microglial absence assists postmigratory cortical neurons in proper differentiation. Nat Commun. (2020) 11:1631. doi: 10.1038/s41467-020-15409-3

80. Katayama T, Kobayashi H, Okamura T, Yamasaki-Katayama Y, Kibayashi $\mathrm{T}$, Kimura $\mathrm{H}$, et al. Accumulating microglia phagocytose injured neurons in hippocampal slice cultures: involvement of p38 MAP kinase. PLoS ONE. (2012) 7:e40813. doi: 10.1371/journal.pone.0040813

81. Neumann J, Sauerzweig S, Rönicke R, Gunzer F, Dinkel K, Ullrich O, et al. Microglia cells protect neurons by direct engulfment of invading neutrophil granulocytes: a new mechanism of CNS immune privilege. J Neurosci. (2008) 28:5965-75. doi: 10.1523/JNEUROSCI.0060-08.2008

82. Ohsawa K, Irino Y, Sanagi T, Nakamura Y, Suzuki E, Inoue K, et al. P2Y12 receptor-mediated integrin-betal activation regulates microglial process extension induced by ATP. Glia. (2010) 58:790-801. doi: 10.1002/glia.20963

83. Petersen MA, Dailey ME. Diverse microglial motility behaviors during clearance of dead cells in hippocampal slices. Glia. (2004) 46:195206. doi: 10.1002/glia.10362

84. Weinhard L, di Bartolomei G, Bolasco G, Machado P, Schieber NL, Neniskyte U, et al. Microglia remodel synapses by presynaptic trogocytosis and spine head filopodia induction. Nat Commun. (2018) 9:1228. doi: 10.1038/s41467-018-03566-5

85. Zhang F, Nance E, Alnasser Y, Kannan R, Kannan S. Microglial migration and interactions with dendrimer nanoparticles are altered in the presence of neuroinflammation. J Neuroinflammation. (2016) 13:65. doi: 10.1186/s12974-016-0529-3

86. Kasahara Y, Koyama R, Ikegaya Y. Depth and time-dependent heterogeneity of microglia in mouse hippocampal slice cultures. Neurosci Res. (2016) 111:64-9. doi: 10.1016/j.neures.2016.05.001

87. Zhang Y, Zhao L, Wang X, Ma W, Lazere A, Qian HH, et al. Repopulating retinal microglia restore endogenous organization and function under CX3CL1-CX3CR1 regulation. Sci Adv. (2018) 4:eaap8492. doi: 10.1126/sciadv.aap8492

88. Cunningham CL, Martínez-Cerdeño V, Noctor SC. Microglia regulate the number of neural precursor cells in the developing cerebral cortex. $J$ Neurosci. (2013) 33:4216-33. doi: 10.1523/JNEUROSCI.3441-12.2013

89. Frakes AE, Ferraiuolo L, Haidet-Phillips AM, Schmelzer L, Braun L, Miranda CJ, et al. Microglia induce motor neuron death via the classical NF-кB pathway in amyotrophic lateral sclerosis. Neuron. (2014) 81:100923. doi: 10.1016/j.neuron.2014.01.013

90. Hupp S, Grandgirard D, Mitchell TJ, Leib SL, Hathaway LJ, Iliev AI. Pneumolysin and the bacterial capsule of Streptococcus pneumoniae cooperatively inhibit taxis and motility of microglia. J Neuroinflammation. (2019) 16:105. doi: 10.1186/s12974-019-1491-7

91. Kraft AD, Kaltenbach LS, Lo DC, Harry GJ. Activated microglia proliferate at neurites of mutant huntingtin-expressing neurons. Neurobiol Aging. (2012) 33:621.e617-633. doi: 10.1016/j.neurobiolaging.2011.02.015

92. Sellgren CM, Gracias J, Watmuff B, Biag JD, Thanos JM, Whittredge $\mathrm{PB}$, et al. Increased synapse elimination by microglia in schizophrenia patient-derived models of synaptic pruning. Nat Neurosci. (2019) 22:37485. doi: 10.1038/s41593-018-0334-7

93. Montilla A, Zabala A, Matute C, Domercq M. Functional and metabolic characterization of microglia culture in a defined medium. Front Cell Neurosci. (2020) 14:22. doi: 10.3389/fncel.2020.00022

94. Rizzi C, Tiberi A, Giustizieri M, Marrone MC, Gobbo F, Carucci NM, et al. NGF steers microglia toward a neuroprotective phenotype. Glia. (2018) 66:1395-1416. doi: 10.1002/glia.23312
95. Wollmer MA, Lucius R, Wilms H, Held-Feindt J, Sievers J, Mentlein R. ATP and adenosine induce ramification of microglia in vitro. J Neuroimmunol. (2001) 115:19-27. doi: 10.1016/s0165-5728(01)00257-0

96. Tam WY, Au NP, Ma CH. The association between laminin and microglial morphology in vitro. Sci Rep. (2016) 6:28580. doi: 10.1038/srep 28580

97. Collins HY, Bohlen CJ. Isolation and culture of rodent microglia to promote a dynamic ramified morphology in serum-free medium. J Vis Exp. (2018) 57122. doi: 10.3791/57122

98. Suzumura A, Sawada M, Yamamoto H, Marunouchi T. Effects of colony stimulating factors on isolated microglia in vitro. J Neuroimmunol. (1990) 30:111-20. doi: 10.1016/0165-5728(90)90094-4

99. Eder C, Klee R, Heinemann U. Involvement of stretch-activated $\mathrm{Cl}^{-}$ channels in ramification of murine microglia. J Neurosci. (1998) 18:7127-37.

100. Hellwig S, Brioschi S, Dieni S, Frings L, Masuch A, Blank T, et al. Altered microglia morphology and higher resilience to stress-induced depressionlike behavior in CX3CR1-deficient mice. Brain Behav Immun. (2016) 55:12637. doi: 10.1016/j.bbi.2015.11.008

101. Socodato R, Henriques JF, Portugal CC, Almeida TO, Tedim-Moreira J, Alves RL, et al. Daily alcohol intake triggers aberrant synaptic pruning leading to synapse loss and anxiety-like behavior. Sci Signal. (2020) 13:eaba5754. doi: 10.1126/scisignal.aba5754

102. Bisht K, Sharma KP, Lecours C, Sánchez MG, El Hajj H, Milior G, et al. Dark microglia: a new phenotype predominantly associated with pathological states. Glia. (2016) 64:826-39. doi: 10.1002/glia.22966

103. Bennett MR. Synaptic P2X7 receptor regenerative-loop hypothesis for depression. Aust $N \quad Z$ J Psychiatry. (2007) 41:563-71. doi: 10.1080/00048670701399994

104. Tremblay M, Stevens B, Sierra A, Wake H, Bessis A, Nimmerjahn A. The role of microglia in the healthy brain. J Neurosci. (2011) 31:160649. doi: 10.1523/JNEUROSCI.4158-11.2011

105. Schafer DP, Lehrman EK, Stevens B. The "quad-partite" synapse: microgliasynapse interactions in the developing and mature CNS. Glia. (2013) 61:2436. doi: $10.1002 /$ glia.22389

106. Ventura R, Harris KM. Three-dimensional relationships between hippocampal synapses and astrocytes. J Neurosci. (1999) 19:6897-906.

107. Genoud C, Quairiaux C, Steiner P, Hirling H, Welker E, Knott GW. Plasticity of astrocytic coverage and glutamate transporter expression in adult mouse cortex. PLoS Biol. (2006) 4:e343. doi: 10.1371/journal.pbio.0040343

108. Shin Y, Choi SH, Kim E, Bylykbashi E, Kim JA, Chung S, et al. Blood-brain barrier dysfunction in a $3 \mathrm{D}$ in vitro model of Alzheimer's disease. Adv Sci. (2019) 6:1900962. doi: 10.1002/advs.2019 00962

109. Shimizu A, Goh WH, Itai S, Hashimoto M, Miura S, Onoe H. ECMbased microchannel for culturing in vitro vascular tissues with simultaneous perfusion and stretch. Lab Chip. (2020) 20:1917-27. doi: 10.1039/d0lc0 $0254 \mathrm{~b}$

110. Goshi N, Morgan RK, Lein PJ, Seker E. A primary neural cell culture model to study neuron, astrocyte, and microglia interactions in neuroinflammation. J Neuroinflammation. (2020) 17:155. doi: 10.1186/s12974-020-0 1819-z

Conflict of Interest: The authors declare that the research was conducted in the absence of any commercial or financial relationships that could be construed as a potential conflict of interest.

Copyright (c) 2021 Andoh and Koyama. This is an open-access article distributed under the terms of the Creative Commons Attribution License (CC BY). The use, distribution or reproduction in other forums is permitted, provided the original author(s) and the copyright owner(s) are credited and that the original publication in this journal is cited, in accordance with accepted academic practice. No use, distribution or reproduction is permitted which does not comply with these terms. 